\title{
Aquatic Surveys and \\ Re-assessment of Sites within the Middle Powder River Watershed
}

Prepared for:

The U.S. Bureau of Land Management - Miles City Field Office

and

The Interagency BLM Aquatic Task Group

Prepared by:

David M. Stagliano

Aquatic Ecologist

Montana Natural Heritage Program

a cooperative program of the

Montana State Library and the University of Montana

May 2012

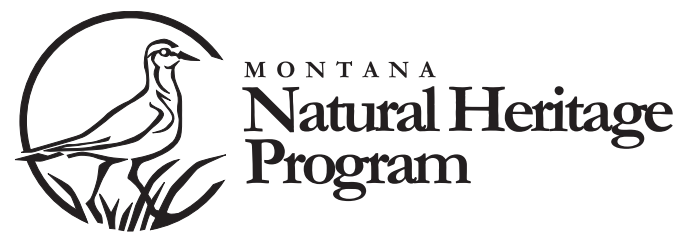





\section{Aquatic Surveys and \\ Re-assessment of Sites within the Middle Powder River Watershed}

Prepared for:

The U.S. Bureau of Land Management - Miles City Field Office

and

The Interagency BLM Aquatic Task Group

Agreement Number:

L08AC13222

Prepared by:

David M. Stagliano

Aquatic Ecologist
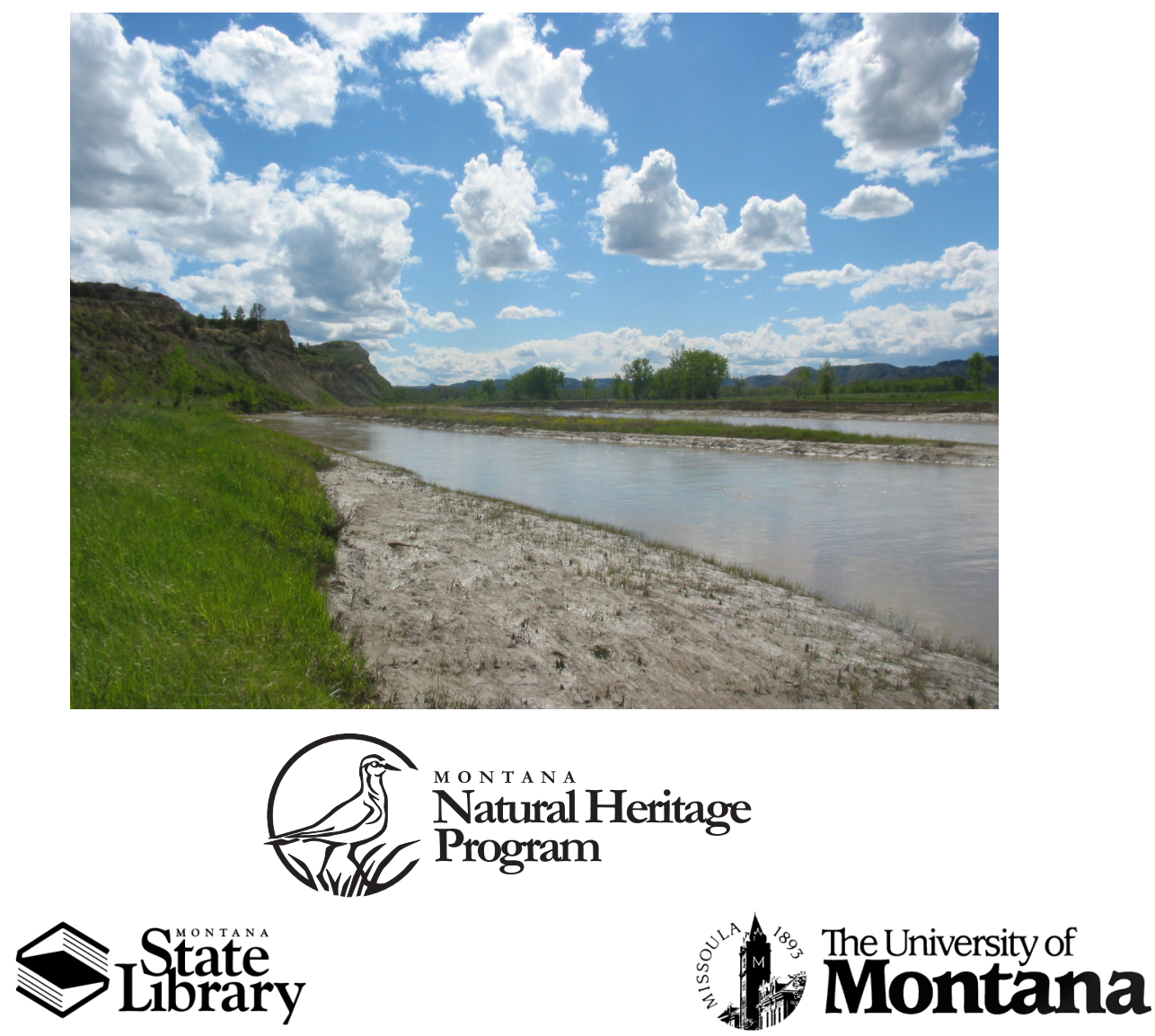

(C) 2012 Montana Natural Heritage Program

P.O. Box 201800 • 1515 East Sixth Avenue • Helena, MT 59620-1800 • 406-444-5354 
This document should be cited as follows:

Stagliano, David M. 2012. Aquatic Surveys and Re-assessment of Sites within the Middle Powder River Watershed. Report for the U.S. Bureau of Land Management, Miles City Field Office and The Interagency BLM Aquatic Task Group. Montana Natural Heritage Program, Helena, Montana. 19 pp. plus appendices. 


\section{Executive Summary}

The project goals of the 2011 Aquatic Surveys and Assessment of the Middle Powder Watershed were to: 1) revisit five integrator sites established and sampled in 2005 to assess aquatic community changes during this time period; 2) perform habitat-targeted surveys for the rare sand-dwelling mayfly community; and 3) interpret key community and watershed indicators (against reference condition standards) to determine aquatic condition status and trends since the development of coalbed natural gas (CBNG) wells in the watershed. Inventory work occurred on BLM lands where possible to enable informed management at the local site scale. Fish and macroinvertebrate samples were collected at six mainstem Powder River sites in Montana (Moorhead Bridge site added in 2011) for this BLM assessment.

Fish Communities: Fish surveys were performed at each site using the $300 \mathrm{~m}$ seining protocols developed by Bramblett et al. (2005) for Montana Fish, Wildlife and Parks. Overall, we captured 374 individuals and identified eight native species at the six mainstem Powder River sites. Despite using the same effort during similar river flows, fish numbers and diversity were significantly lower (about $1 / 4$ as many individuals) in 2011 than in 2005, which recorded 1299 individuals of 13 fish species. Native fish species averaged six per site in 2011, whereas in 2005, sites averaged seven per site $(7.5$ species is Expected $\{E\}$ at reference condition). Flathead chubs were the dominant members of this river section's fish community in 2011 averaging $66 \%$ of the individuals collected, while in 2005 they only made up about $28 \%$ with sand shiners dominating the catch $(60 \%)$. The exotic carp and introduced plains killifish were not collected at any of the 2011 sites where they were reported in 2005. The Sturgeon Chub, a Montana species of concern previously common in this reach, was not collected in 2011 and only at one downstream site in 2005, indicating a sustained decline or absence in this reach. Fish communities across all sites scored relatively lower with the IBI and Observed vs. Expected $(\mathrm{O} / \mathrm{E})$ in 2011 than in 2005 (averaging 54.8 vs. 58.4 and 0.8 vs. 0.9 , respectively), but these differences were not significant (F-test, $p=0.25$ and 0.74). The Moorhead Bridge site was the exception for 2011 with increased IBI and O/E scores. When calculating $\mathrm{O} / \mathrm{E}$ values, four of the six sites scored within the 1.2-0.8 unimpaired/good integrity threshold, while sites POW3 and POW6 ranked impaired with scores of 0.57 and 0.63 . The fish community scores did not correlate with the macroinvertebrate DEQ MMI or O/E scores ( $\mathrm{r}=0.09$ and 0.07 ), but did have a positive relationship with the BLM Habitat Scores ( $\mathrm{r}=0.51$ and 0.55 ).

Macroinvertebrate Communities: Paired EMAP-protocol macroinvertebrate samples were collected at each site replicating efforts from 2005. Overall, 64 total taxa were reported from the sites in 2011, an increase from 59 taxa in 2005. Average macroinvertebrate-taxa richness per site was 28 taxa, which is a significant increase from 23.4 taxa per site reported in $2005(\mathrm{p}<0.03)$. All EMAP samples agreed in ranking the six Powder River sites non-impaired with DEQ MMI plains-index scores $>37$ and the $\mathrm{O} / \mathrm{E}$, but the $\mathrm{O} / \mathrm{E}$ scores based on species expected only $>50 \%$ of the time report all sites significantly below the impairment threshold. Reach-Wide EMAP samples collected two of the five species of rare sanddwelling mayflies, Homoeoneuria alleni and Anepeorus rusticus not sampled with the Targeted-Riffle Protocols (Peck et al. 2003). Targeted sampling of the rare sand-dwelling mayfly community with the over-sized dip net proved laborious and ineffective at increasing occurrence records or estimating densities. 
There were no discernible trends in the MMI or $\mathrm{O} / \mathrm{E}$ index scores from the Wyoming Border to Broadus, and MMI scores were not significantly different than 2005 scores. However, the occurrence and abundance of some sensitive/Species of Concern (SOC) mayfly species has significantly decreased from the Wyoming Border to Moorhead Bridge from 2005 to 2011, while the abundance of the stonefly, $A c$ roneuria abnormis, has significantly increased across the study area in recent years.

Community Integrity: Multiple lines of evidence (fish and macroinvertebrates) indicate a continued decline in the biological integrity of this reach of the Powder River. This is particularly noted in fish and SOC mayfly species declines between the Wyoming border and Moorhead Bridge. From a long-term perspective, the fish community at the WY border looks significantly different than it did 30 years ago, as it continues to lose sensitive species and biological integrity. Concurrent studies have found that the maximum concentrations of alkalinity in the Powder River also occurred in this reach (Petersen et al. 2011), potentially implicating cumulative effects from coalbed natural gas extraction-related outflows from upstream in Wyoming as likely contributors to this biological condition. Community Integrity results from the 2011 fish and macroinvertebrate surveys combined to rank the Powder River reach at the Moorhead Bridge Site as the most biologically intact, followed by Powder River Site \#5 upstream of Rough Creek (POW\#5). In 2005, the Powder River reach at the Wyoming border (POW\#1) and POW\#5 had the highest index of biotic integrity (IBI) for fish. Powder River Site \#5 was also the only site where we collected Sturgeon Chubs (Montana SOC) in 2005, but we failed to collect any during the 2011 sampling. 


\section{ACKNOWLedgements}

We would like to thank The Interagency Aquatic Task Group (ATG) of the Bureau of Land Management (BLM), especially Jake Chaffin of the Miles City Field Office and Bill Ostheimer of Buffalo, Wyoming BLM FO, for support and funding of MTNHP aquatic ecological projects. We also thank Dave Feldman (MTDEQ) for running the 2011 macroinvertebrate O/E models. Dr. Dan Gustafson, provided important information about his research
We wish to thank those who assisted us in the field sampling, including Troy Hinke (Broadus) and Winston Greeley (Helena) of MTFNP. Substantial on-site field sampling and logistic help were provided by Bryce Maxell (MTNHP). Editorial comments were provided by MTNHP staff members Linda Vance, Gary Carnefix, and Neil Snow. Coburn Currier formatted and provided helpful comments on the report. This is publication no. 2012-03 of the Montana Natural Heritage Program. 


\section{Table of Contents}

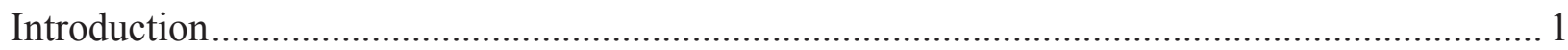

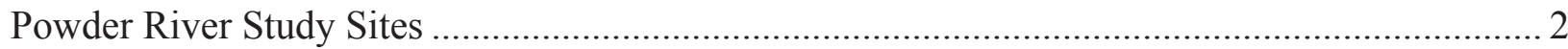

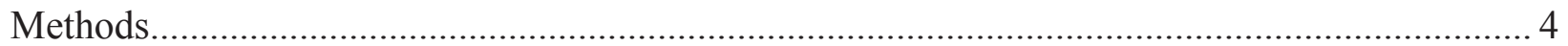

Habitat and Water Quality Collection and Analysis ............................................................. 4

Fish Collection and Analysis ...................................................................................... 4

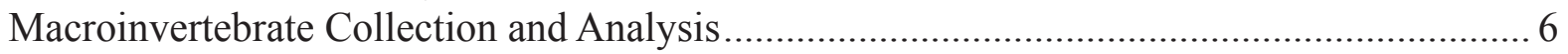

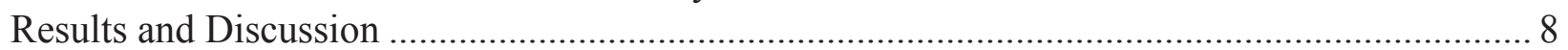

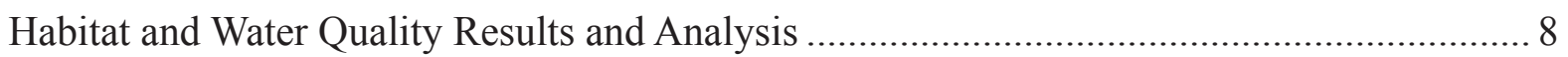



Macroinvertebrate Community Analysis .......................................................................... 12

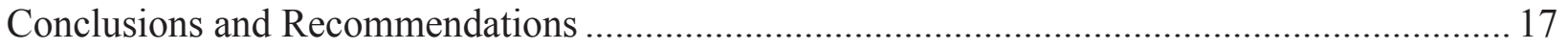

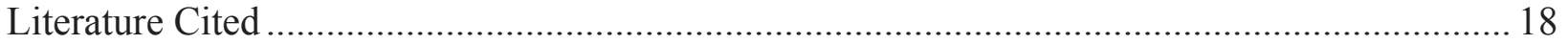

Appendix A: Global/State Rank Definitions

Appendix B: Raw fish data and IBI metric calculation from Powder River sites.

Appendix C: Macroinvertebrate taxa lists, abundance and plains MMI calculations at each site.

\section{List OF Figures}

Figure 1. Aquatic Sample sites in the Middle Powder River Watershed ..................................... 3

Figure 2. Seining the Powder River near the WY border ........................................................ 4

Figure 3. Reach-wide EMAP macroinvertebrate sample (F pin center) at Powder

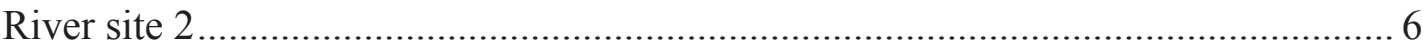

Figure 4. Two native catfish species collected in the Powder River........................................... 8

Figure 5. Powder River fish community IBI and Observed/Expected (O/E) Scores for

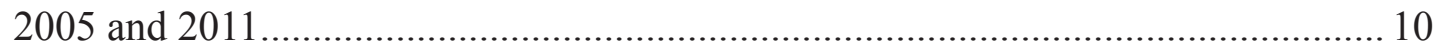

Figure 6. Powder River study reach fish community proportion for the dominant 8 species by total individuals in 2005 and 2011 .................................................... 11

Figure 7. Individual species responses across sites and years of the SOC mayfly and

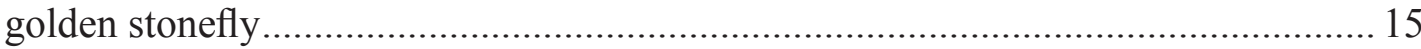

Figure 8. Powder River study reach macroinvertebrate IBI and O/E Scores for 2005

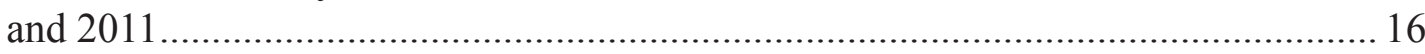

\section{List OF TABLES}

Table 1. Powder River Site locations sampled in 2011 ...................................................... 2

Table 2 Characteristics, metrics, and classification of fish captured in the Powder River during 2005 and 2011 sampling................................................................... 5

Table 3. Impairment determinations from the MMI and O/E models ..................................... 7

Table 4. Habitat quality scores, physical and water quality parameters of Powder

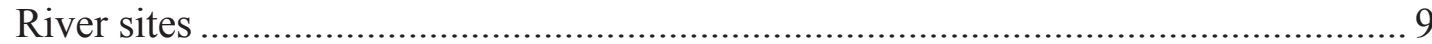

Table 5. Fish collected from the mainstem Powder River, IBI and O/E index scores .............. 9

Table 6. Powder River fish samples at the Wyoming border taken 30 and 36 years apart...... 12

Table 7. Powder River macroinvertebrate sample information................................................ 13 


\section{List OF TABLEs (CONTINUED)}

Table 8. Sensitive and SOC macroinvertebrate species site occupancy changes

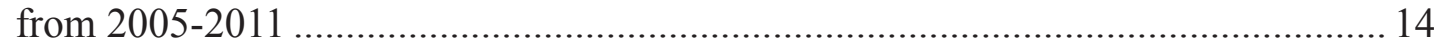

Table 9. Sand-dwelling SOC taxa collected with the EMAP RW vs. Sandbar

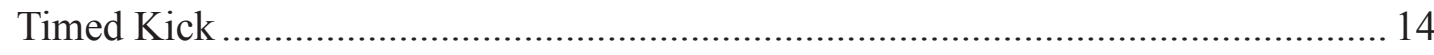





\section{INTRODUCTION}

The Powder River is a vast drainage representing one of the last undammed, large prairie rivers in the United States. In this part of southeastern Montana, the landscape through which the Powder flows resembles a natural condition-state of a large prairie river with sweeping meanders across the valley bottom, side channels, oxbows, shifting islands and functional connectedness to the floodplain (Vance et al. 2006). The Powder River aquatic ecosystem supports many elements of a fully functioning, biologically diverse system, including 25 native fish species (19 in Montana) (Baxter and Stone 1995) and numerous species of rare invertebrates. Some mayfly and dragonfly species of concern (SOC), including globally rare (G1-G3) species, have evolved to exploit the shifting sand and gravel bar habitats common in unaltered large prairie rivers (D. Gustafson, pers. comm. 2006, Stagliano 2006, MTNHP and MTFWP 2006). With its specialized aquatic life, the Powder River supports not only a diverse community, but represents the sole remnant of a once widespread Great Plains riverine community of fish and invertebrates (Hubert 1993). The Powder River was identified as the reference standard in the Large Prairie River classification (Stagliano 2006); no other large prairie system in the ecoregion contains the quality and biological integrity of its communities and habitats (Stagliano 2005). Furthermore, the Powder River was determined to provide substantial habitat for the declining sturgeon chub (Montana and Wyoming SOC, BLM Sensitive Species) (Werdon 1992), a species that has been extirpated from much of its historic range (Stagliano and Gould 2010).

The Powder River Basin in Wyoming and Montana is currently undergoing one of the world's largest coalbed natural gas (CBNG) developments, with about 12,000 wells in place in 2003, 14,200 in 2005 , and up to 70,000 projected over the next 20 to 30 years (Davis and Bramblett 2006). CBNG mining has the potential to severely disrupt biota in adjacent riparian zones and streams. However, information is scarce concerning the effects of CBNG product water on fish and aquatic inverte- brates, making it difficult to predict the potential effects of this development on aquatic ecosystems (Davis et al. 2009). Therefore, pre-development baseline data and monitoring can be used to assess the influence of CBNG wells at the landscape or local reach scale. Despite numerous projects undertaken to document and monitor biological communities in the middle Powder River watershed (Confluence Consulting 2004; Stagliano 2006; Davis et al. 2009; Peterson et al. 2009; Peterson et al. 2011), gaps still exist in our basic knowledge of prairie river aquatic community spatial and temporal changes without the addition of confounding anthropogenic factors (Dodds et al. 2004). Additionally, the Powder River presents numerous challenges in evaluating its biological and chemical integrity. These include problems associated with sampling a shifting sand-bed stream, high variability in flow, and naturally high conductivity and turbidity.

Structural changes have been documented in the fish assemblages since the 1970s in the present study section of the Powder River from dominance by flathead chub (Platygobio gracilis) to dominance by sand shiner (Notropis stramineus) (Stagliano 2006, Peterson et al. 2010). This change has been coupled with a continued decline of the sturgeon chub (Macrhybopsis gelida) throughout the Powder River (Stagliano and Gould 2010) and increased occurrences of introduced fish species (Patton et al. 1998). Therefore, additional monitoring is warranted within the targeted locations between the Wyoming border and Broadus.

This study represents a continued investigation into documenting the fish and macroinvertebrate communities of this prairie river section with these specific objectives: 1) to revisit and resample six integrator sites established in 2005 to assess aquatic community changes over this time period; 2) to perform habitat-targeted surveys for the rare sanddwelling mayfly community; and 3) to interpret key community and watershed indicators (against reference condition standards) to determine aquatic condition status and trends during the development of CBNG wells in the watershed. 


\section{Powder River Study Sites}

Joseph Platz (former BLM Miles City Fish

Biologist) and I established the following sites

in 2005 along the main-stem Powder River on

BLM or state-owned riparian parcels that were

"two track" accessible and would complement on-

going USGS monitoring sites. We keep the initial

naming convention of the sites despite dropping

site 4 and inserting Site 6 upstream of Site 5. We

added the Moorhead Bridge site in 2011 after

conversations with Jake Chaffin (BLM Miles City)

(Figure 1, Table 1).

Table 1. Powder River Site locations sampled in 2011.

\begin{tabular}{|c|c|c|c|c|c|c|c|}
\hline Site Code & Site Description & $\begin{array}{c}\text { River } \\
\text { Mile }\end{array}$ & Latitude & Longitude & Elevation & $\begin{array}{c}\text { Reach } \\
\text { Gradient }\end{array}$ & $\begin{array}{c}\text { Date } \\
\text { Sampled }\end{array}$ \\
\hline POW1 & $\begin{array}{l}\text { Powder River near } \\
\text { Wyoming border }\end{array}$ & 219 & 45.0128 & -105.9029 & 3426 & $0.5 \%$ & $7 / 26 / 2011$ \\
\hline POW2 & $\begin{array}{l}\text { Powder River near } \\
\text { Dry Creek }\end{array}$ & 215 & 45.0377 & -105.8809 & 3376 & $0.3 \%$ & $7 / 26 / 2011$ \\
\hline POWMOOR12 & $\begin{array}{l}\text { Powder River at } \\
\text { Moorhead bridge }\end{array}$ & 212 & 45.0578 & -105.8775 & 3350 & $0.4 \%$ & $7 / 27 / 2011$ \\
\hline POW3 & $\begin{array}{l}\text { Powder River } \\
\text { downstream from } \\
\text { Moorhead }\end{array}$ & 206 & 45.1071 & -105.8421 & 3315 & $0.2 \%$ & $7 / 27 / 2011$ \\
\hline POW6 & $\begin{array}{l}\text { Powder River near } \\
\text { Buttermilk Creek }\end{array}$ & 187 & 45.2256 & -105.6906 & 3185 & $0.2 \%$ & $7 / 27 / 2011$ \\
\hline POW5 & $\begin{array}{l}\text { Powder River near } \\
\text { Rough Creek }\end{array}$ & 166 & 45.3467 & -105.5333 & 3105 & $0.2 \%$ & $7 / 28 / 2011$ \\
\hline
\end{tabular}




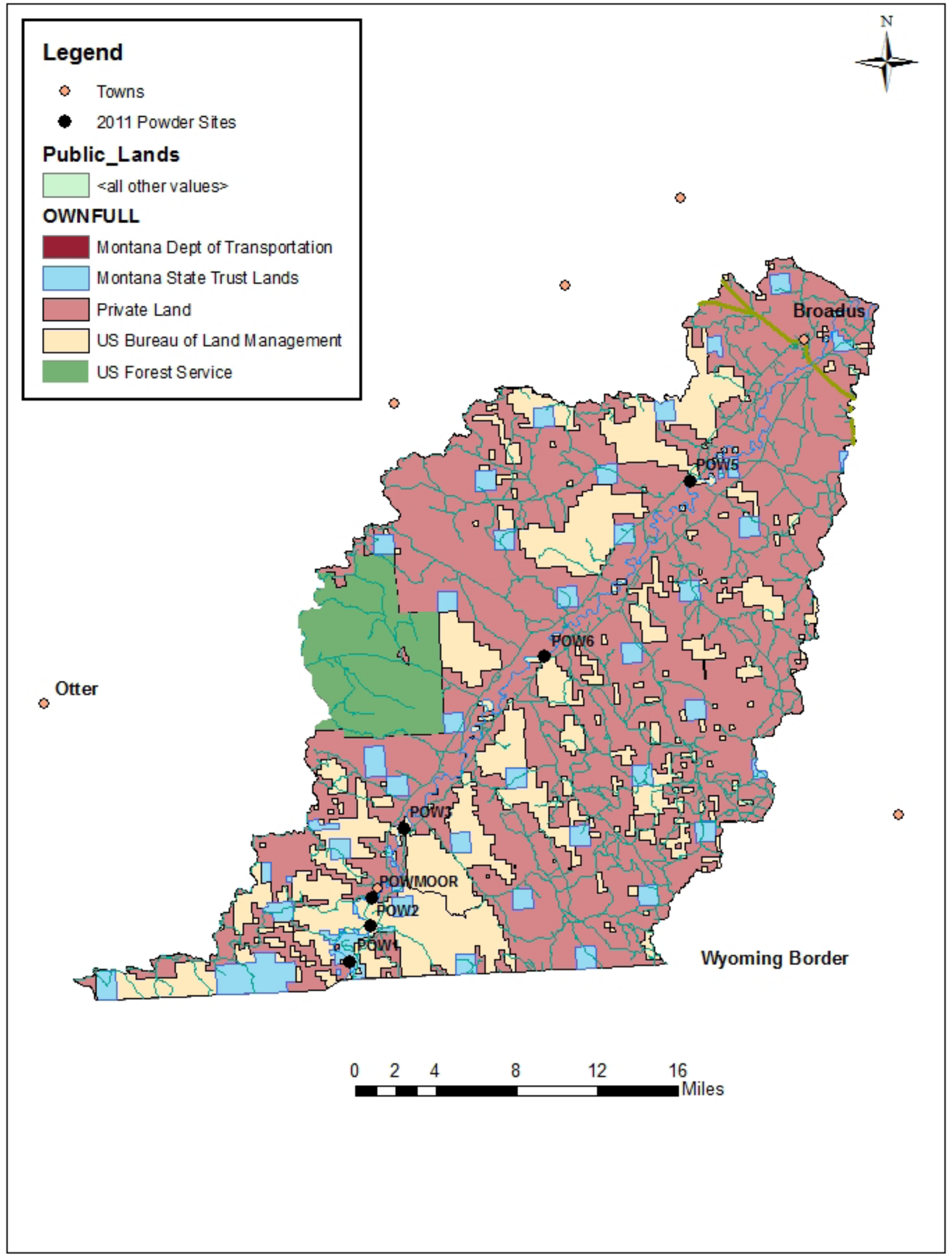

Figure 1. Aquatic Sample sites in the Middle Powder River Watershed. 


\section{Methods}

Aquatic communities (fish and macroinvertebrates) and riparian areas were inventoried and assessed using a combination of Montana Fish, Wildlife and Parks (MFWP) (fish) and BLM / EPA (macroinvertebrates and habitat assessments) protocols and methodology. These methods replicated those used during our July 2005 site visits during river flows at $500 \mathrm{cfs}$ (recorded at the USGS Moorhead Gaging Station). Reach lengths were set at a standard $300 \mathrm{~m}$, but to encompass an additional set of riffle macrohabitats for the macroinvertebrate targeted-riffle sampling, protocols were extended to $450 \mathrm{~m}$. Information and results from previous inventories, such as those conducted by MTFWP (fish), USGS and BLM (macroinvertebrates), were incorporated into the analysis for Moorhead Bridge (in 2005) and earlier site visits for the Wyoming border site.

\section{Habitat and Water Quality Collection and Analysis}

The assessment stream reach was divided into 10 equally spaced transects according to the BLM and EMAP protocols (http://www1.usu.edu/buglab/ forms $/ \mathrm{Bug} \% 20$ Protocol $\% 20$ form.pdf; Lazorchak et al. 1998). The downstream transect was marked (GPS, flagging and photo point) as the bottom of the reach. All ecological assessment protocols started from this point and continued upstream for $300 \mathrm{~m}$ (designated the assessment area or "AA") to the top of the reach, which was also marked.

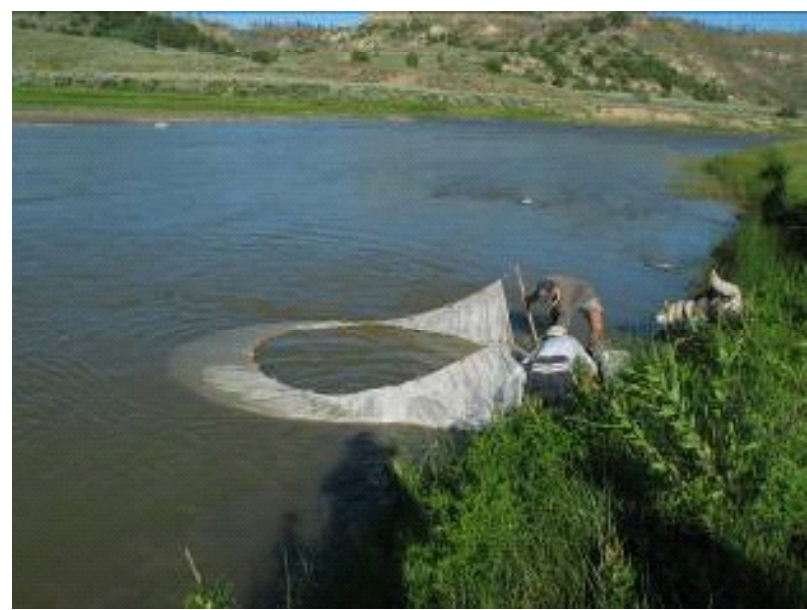

Parameters recorded at each transect were: wetted width; three channel depth measurements; percent large woody debris and riparian shading. Onsite habitat assessments were conducted using the rapid assessment protocol developed for the EPA by Barbour et al. (1999), with modifications for the BLM by the National Aquatic Assessment Team (scores 0-24). Water quality measures: Specific conductivity; $\mathrm{pH}$; water temperature; and dissovlved oxygen concentration were measured prior to biological sampling, which used a Yellow Springs Instruments Inc. Model 85 water meter calibrated to the higher conductivity level.

\section{Fish Collection and Analysis}

Fish surveys were performed using the $300 \mathrm{~m}$ seining protocols developed by Bramblett et al. (2005) for Montana Fish, Wildlife and Parks. This protocol calls for block nets at the upstream and downstream ends of the reach, but the width of the Powder River precluded the use of these. Instead, shallow riffle areas were used as barriers and appeared sufficient in preventing fish from escaping while the run and pool areas were being seined (Figure 2). Shallow riffle areas unable to be seined in the normal fashion because of cobble obstructions were "kick-seined" (Figure 2) to capture fish inhabitating this microhabitat. We used $30 \mathrm{ft}, 1 / 4$ inch mesh seines to cover most areas across the channel and all macrohabitats within the reach.

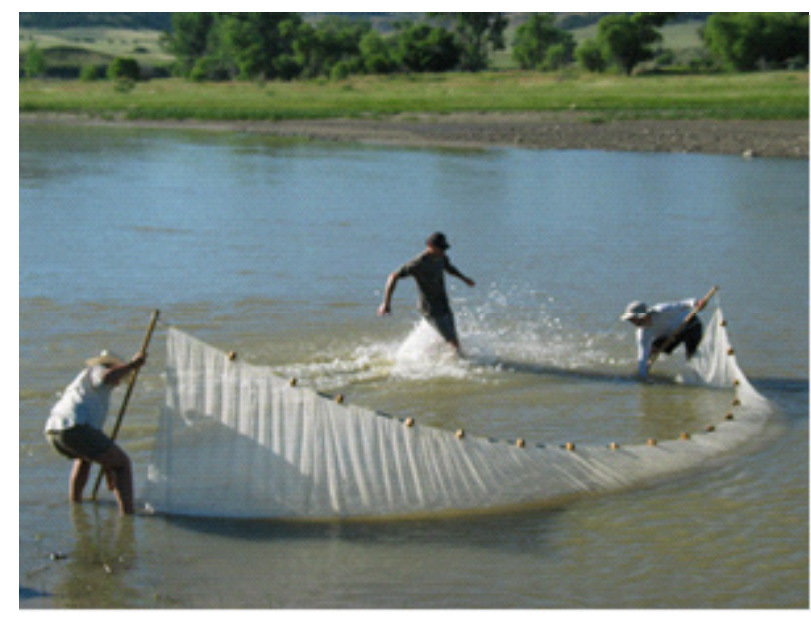

Figure 2. Seining the Powder River near the Wyoming border by beach seining (l) and kick-seining a riffle (r). 
Fish were transferred to holding buckets, identified to species, enumerated in the field, examined for external anomalies (e.g. deformities, eroded fins, lesions, and tumors), and released. Young-of-theyear fish less than 20 millimeters in length were noted on the field sheet (not included in the totals), and released. Voucher specimens were taken only in the case of uncertain field identifications of the silvery minnows, Hybognathus spp., which were preserved in 10\% buffered formalin and identified in the lab. Vouchers will be submitted to the Montana State University fish collection. Analysis of the sampled fish communities used
Integrated Biotic Indices (IBI) (Bramblett et al. 2005) and derived Observed/Expected (O/E) fish models (Stagliano 2005) to detect impairment or species loss in the biological integrity of the sites. The IBI involved calculation of a series of 10 metrics evaluating different attributes of the fish community (Table 2, Appendix B).

Because fish species richness can be directly proportional to watershed size and is a multiplicative factor in the Montana IBI (Bramblett et al. 2005), we used the average catchment area for this study reach $\left(20,962 \mathrm{~km}^{2}\right)$ based at the

Table 2. Characteristics, metrics, and classification of fish captured in the Powder River during 2005 and 2011 sampling. $\quad *=$ species collected in 2005, but not in 2011.

\begin{tabular}{|c|c|c|c|c|c|c|}
\hline Species & Scientific Name & Trophic* & $\begin{array}{l}\text { Feeding } \\
\text { Habitat } \uparrow\end{array}$ & $\begin{array}{c}\text { Litho-obligate } \\
\text { Reproductive } \\
\text { Guild } \$\end{array}$ & Tol** & Origin $t_{\dagger}$ \\
\hline \multicolumn{7}{|l|}{ Hiodontidae } \\
\hline Goldeye & Hiodon alosoides & IN & WC & LO & INT & $\mathrm{N}$ \\
\hline \multicolumn{7}{|l|}{ Catostomidae } \\
\hline River Carpsucker* & Carpiodes carpio & $\mathrm{OM}$ & $\mathrm{BE}$ & LO & MOD & $\mathrm{N}$ \\
\hline Shorthead Redhorse* & $\begin{array}{l}\text { Moxostoma } \\
\text { macroledidotum }\end{array}$ & IN & $\mathrm{BE}$ & LO & MOD & $\mathrm{N}$ \\
\hline \multicolumn{7}{|l|}{ Cyprinidae } \\
\hline Common Carp* & Cyprinus carpio & $\mathrm{OM}$ & $\mathrm{BE}$ & & TOL & I \\
\hline Flathead Chub & Platygobio gracilis & IN & GE & & MOD & $\mathrm{N}$ \\
\hline Longnose Dace & Rhinichthys cataractae & IN & $\mathrm{BE}$ & LO & INT & $\mathrm{N}$ \\
\hline Plains Minnow & Hybognathus placitus & $\mathrm{HB}$ & $\mathrm{BE}$ & & MOD & $\mathrm{N}$ \\
\hline $\begin{array}{l}\text { Western silvery } \\
\text { Minnow }\end{array}$ & Hybognathus argyritis & $\mathrm{HB}$ & $\mathrm{BE}$ & & MOD & $\mathrm{N}$ \\
\hline Sand Shiner & Notropis stramineus & $\mathrm{OM}$ & GE & LO & MOD & $\mathrm{N}$ \\
\hline Sturgeon Chub* & Macrhybopsis gelida & IN & $\mathrm{BE}$ & LO & INT & $\mathrm{N}$ \\
\hline \multicolumn{7}{|l|}{ Cyprinidontidae } \\
\hline Plains Killifish* & Fundulus kansae & $\mathrm{OM}$ & GE & & TOL & I \\
\hline \multicolumn{7}{|l|}{ Ictaluridae } \\
\hline Channel Catfish & Ictalurus punctatus & IC & $\mathrm{BE}$ & $\mathrm{TR} \S$ & MOD & $\mathrm{N}$ \\
\hline Stonecat & Noturus flavus & $\mathrm{IC}$ & $\mathrm{BE}$ & LO & INT & $\mathrm{N}$ \\
\hline
\end{tabular}

${ }^{\wedge} \mathrm{HB}=$ herbivore $(>90 \%$ plants or detritus); $\mathrm{IC}=$ invertivore/carnivore $(>25 \%$ both invertebrates and vertebrates $)$; IN = invertivore; OM =

$\dagger \mathrm{BE}=$ benthic; $\mathrm{GE}=$ generalist; $\mathrm{WC}=$ water column: Brown (1971); Scott and Crossman (1973); Becker (1983)

$\$$ LO=Litho-obligate Reproductive Guild; Scott and Crossman (1973); Pflieger (1997); Barbour et al. (1999)

$\S$ Tolerant reproductive strategists are not litho-obligates, use parental care at spawning site: Scott and Crossman (1973); Pflieger (1997)

** INT = intolerant; MOD = moderately tolerant: TOL = tolerant; Barbour et al. (1999);

$\dagger \dagger \mathrm{N}=$ native; $\mathrm{I}=$ introduced; Brown (1971); Holton and Johnson (2003) 
Moorhead gauging station for these calculations. The summation of individual fish species and tolerance metrics range between 0 and 100 . Bramblett et al. (2005) did not propose threshold criteria for good, fair, and poor biological integrity for these scores, but instead relied on comparisons to "reference condition" scores. Therefore, we followed Confluence Consulting (2004) methods by applying commonly used criteria of 75 to 100 indicating good to excellent biological integrity, 25 to 74 indicated fair biological integrity, and less than 25 indicating poor biological integrity in describing condition.

Derivation of the expected fish communities is performed by identifying the frequency of occurrence that a species has at a site classified in a reference condition and summing the frequencies across all fish species of the community (see Stagliano 2006). The O/E (Observed taxa of an evaluated site/Expected Taxa for a reference site) model is a direct measure of the community completeness. Taxonomic completeness is a fundamental aspect of biological integrity and is defined here as the proportion of the taxa that "should" occur in a sample (E) that were actually sampled (O) (Jessup et al. 2005). It compares the fish species that are expected at a site with the actual taxa that were found when the site was sampled (carp/introduced species are never "expected" and thus were given scores of zero). Values of the O/E range from 0 to 1 , with values of 1 implying reference conditions and values less than 1 implying some form of biological impairment. In some cases, it is more ecologically meaningful than the IBI, but not always. Pairs of fish community samples were compared across years for significant differences by using proportional and taxa community similarity indices (Brower and Zar 1984).

\section{Macroinvertebrate Collection and Analysis}

The two standardized macroinvertebrate methods used for the mainstem Powder River monitoring were the EMAP Targeted Riffle (8 composited riffle Surber samples, area sampled $=0.744$ square meters) and the EMAP Reach-Wide sampling for including all habitats within the sampling reach (10 dipnets, area sampled was ca. 0.93 square meters) (Lazorchak et al. 1998, Peck et al. 2003) (Figure 3).

These samples were collected within the MTDEQ recommended sampling time frame (June $1^{\text {st }}$. September $\left.15^{\text {th }}\right)$, preserved in 1 liter Nalgene



Figure 3. Reach-wide EMAP macroinvertebrate sample (F pin center) at Powder River Site 2. 
bottles with $95 \%$ ethanol and processed (sorting, identification and data analysis) by David Stagliano at the MTNHP Helena lab following protocols used by the BLM Buglab: http://www1. usu.edu/buglab/process/lab\%20procedures. htm. Macroinvertebrates were identified to species, counted and the tabular data entered into spreadsheet and database forms. Data analysis included computation of indices of community structure such as proportion of EPT (\% Ephemeroptera, Plecoptera and Trichoptera taxa) and other biological metrics used in calculating the MTDEQ multimetric macroinvertebrate (MMI) indices or used in the Observed /Expected $(\mathrm{O} /$

E) Models (Jessup et al. 2005, Feldman 2006). Metric results were then scored using the MTDEQ bioassessment criteria and each sample categorized as non-impaired or impaired according to threshold values (Table 3 ). The macroinvertebrate MMI score is based upon a series of metrics that measure attributes of benthic macroinvertebrate communities regarding condition changes to a stream system (in the form of pollution or pollutants). The invertebrate metrics include: EPT Taxa Richness $($ Score $=$ EPT richness/14*100): Ephemeroptera, Plecoptera andTrichoptera taxa; Percent Tanypodinae $($ Score $=$ Percent Tanypodinae $/ 10 * 100$ )[ Tanypodinae is a subfamily of Chironomidae]); Percent Orthocladiinae of Chironomidae (Score $=(100$-percent Orthocladiinae of Chironomidae/100)*100); Predator Taxa Richness (Score $=$ number of predator taxa/9*100); Percent Collectors and
Filterers $($ Score $=(100-$ percent collectors and filterers/65)*100. The index score represents the condition of the macroinvertebrate community at the time the sample was collected. If the index score is below the impairment threshold, the individual metrics can be used to provide insight as to why the communities are different from the reference condition (Barbour et al. 1999, Jessup et al. 2005). The results from the eastern plains index metrics are averaged to obtain the final index score. The impairment threshold set by MTDEQ is 37 for the eastern plains stream MMI index and $<0.8$ for the $\mathrm{O} / \mathrm{E}$ (Table 3 ). Ideal scores representing a "complete" community are between 0.8 and 1.2 where a score of 1.0 represents $100 \%$ of the expected species were actually collected. The O/E scores can be evaluated by summing all taxa expected at a given site $(0 / \mathrm{E} \mathrm{p}>0)$, or by summing only those taxa expected to be at the site greater than $50 \%$ of the time $(\mathrm{O} / \mathrm{E} \mathrm{p}>0.5)$. The latter method has been found to eliminate the "eschewing" effect of counting too many rare taxa in the sample (Marchant 2002).

The final invertebrate sampling method targeted main current, sand-dwelling invertebrates with a modified 0.5 meter rectangular dipnet (D. Gustafson, pers. comm. 2006). The dipnet was maneuvered downstream of the sampler in a diagonal fashion as the sampler is kicking both feet across main-current sandbars using a timedistance catch-per-unit-effort (CPUE) measure to standardize across all reaches sampled in the Powder River.

Table 3. Impairment determinations from the DEQ MMI and O/E (RIVPACS) models (taken from Jessup 2005, Feldman 2006).

\begin{tabular}{l|l|l|l} 
Ecoregion & RIVPACS & MMI & Impairment Determination \\
\hline Mountain & $\geq 0.8$ or $\leq 1.2$ & $\geq 63$ & Not impaired \\
& $<0.8$ or $>1.2$ & $<63$ & Impaired \\
Low Valley & $\geq 0.8$ or $\leq 1.2$ & $\geq 48$ & Not Impaired \\
& $<0.8$ or $>1.2$ & $<48$ & Impaired \\
Eastern Plains & $\geq 0.8$ or $\leq 1.2$ & $\geq 37$ & Not impaired \\
& $<0.8$ or $>1.2$ & $<37$ & Impaired
\end{tabular}




\section{Results AND Discussion}

\section{Habitat and Water Quality Results and Analysis}

Powder River Sites 1 and 5 scored highest in habitat quality with the BLM assessment protocols, representing $75 \%$ and $80 \%$ of the best possible score, respectively (Table 4). Powder Site 5 also had the highest number of recorded channel depths greater than $50 \mathrm{~cm}$, indicating ample deep holding areas for fish. Powder River Site 3 scored lowest in the habitat assessment scores despite having the second highest number of deep channel areas; unfortunately, many of these deep areas had unstable, unconsolidated substrate (silt, fine sand), which is not optimum fish habitat.

Conductivity measurements were calibrated with the USGS field gauge at the Moorhead Bridge site. Reach-wide conductivity values measured in 2011 averaged slightly higher $(1225 \mu \mathrm{s} / \mathrm{cm})$ than in $2005(1190 \mu \mathrm{s} / \mathrm{cm})$, but were not significantly different (F-test, $\mathrm{p}>0.05$ ). Temperature increases of $>6$ degrees $\mathrm{C}$ and slight decreases in dissolved $\mathrm{O}^{2}(>1 \mathrm{mg} / \mathrm{l})$ can be seen in the sequence of sites Moorhead Bridge $\rightarrow$ POW $\rightarrow$ POW6 as they were sampled on $7 / 27 / 2011$ from the morning hours into the late afternoon (Table 4).

\section{Fish Community Results and Analysis}

We captured 374 individuals and identified eight native fish species at the six Powder River sites (Table 5). Despite using the same effort during similar river flows, fish numbers per site and diversity were significantly lower in 2011 than in 2005 (1299 individuals of 13 fish species). Whereas in 2005, sites averaged 7 spp. per site, in 2011 native fish averaged 6 species per site $(7.5$ species is expected at reference condition). The exotic carp and introduced plains killifish were not collected at any of the 2011 sites where they were reported in 2005, nor were the native shorthead redhorse or river carpsucker (Table 5). The Sturgeon Chub, a Montana and Wyoming species of concern previously common in this reach, was not collected in 2011 and only at one downstream site in 2005, indicating a sustained population decline or absence in this study reach.

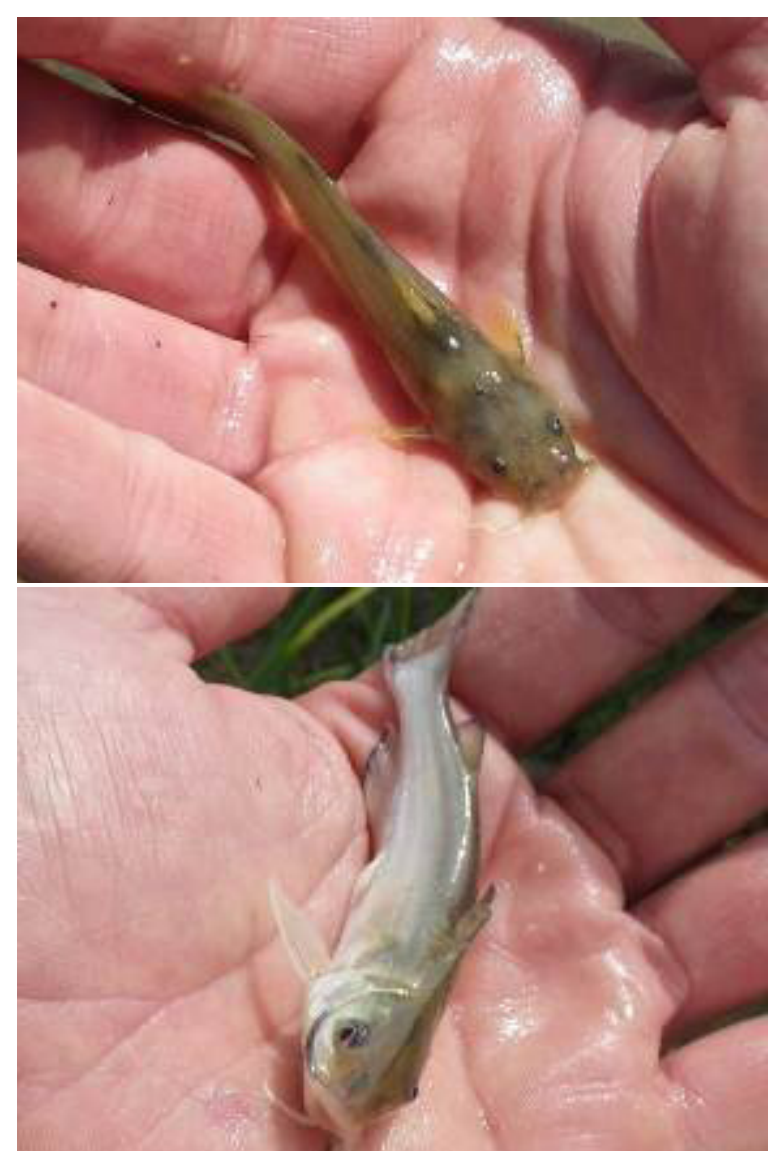

Figure 4. Two native catfish species collected in the Powder River, the stonecat (top) and channel catfish (bottom).

Fish communities across all sites scored relatively lower with the IBI and O/E in 2011 than in 2005 (averaging 54.8 vs. 58.4 and 0.8 vs. 0.9 , respectively) (Figure 5). However, these differences were not significant (F-test, $\mathrm{p}=0.25$ and 0.74). At the site level, there were substantial decreases in the IBI at sites POW1 and POW5 between 2005 and 2011; the exception to this declining trend was the Moorhead Bridge site, which had a slightly increased IBI and O/E scores (Figure 5). The $\mathrm{O} / \mathrm{E}$ at four of the six sites scored within the 1.2-0.8 unimpaired/good integrity threshold, while sites POW3 and POW6 ranked impaired with scores of 0.53 and 0.67 (Table 5, Figure 5). 
Table 4. BLM Habitat Quality scores (out of 24), physical and water quality parameters of Powder River sites. $C h D=$ channel depths measured in 10 cross sections $(n=30)$, \# of ChD $>50 \mathrm{~cm}$ reflects deep run or pool areas. Cond ${ }^{*}=$ Conductivity in microsiemens $/ \mathrm{cm}, \mathrm{DO}=$ Dissolved Oxygen in $\mathrm{mg} / \mathrm{l}$.

\begin{tabular}{lcccccccc}
\hline Site & $\begin{array}{c}\text { BLM } \\
\text { Site } \\
\text { Score }\end{array}$ & $\begin{array}{c}\text { Avg } \\
\text { wetted } \\
\text { width (m) }\end{array}$ & $\begin{array}{c}\text { Avg } \\
\mathbf{C h D} \\
(\mathbf{c m})\end{array}$ & $\begin{array}{c}\text { \# ChD } \\
>\mathbf{5 0} \mathbf{~ c m}\end{array}$ & $\begin{array}{c}\text { T2O } \\
\text { Temp } \\
\left({ }^{\circ} \mathbf{C}\right)\end{array}$ & pH & Cond* & DO \\
\hline Powder River 1 & 18 & 42.4 & 36.0 & 6 & 23.3 & 8.5 & 1180 & 8.0 \\
Powder River 2 & 16 & 38.5 & 40.0 & 8 & 24.5 & 8.4 & 1160 & 7.8 \\
Powder MOOR12 & 17 & 37.0 & 45.0 & 11 & 22.7 & 8.5 & 1180 & 8.2 \\
Powder River 3 & 16 & 44.0 & 44.0 & 15 & 27.7 & 8.6 & 1210 & 7.8 \\
Powder River 6 & 15 & 45.0 & 32.0 & 7 & 28.5 & 8.4 & 1302 & 7.0 \\
Powder River 5 & 20 & 42.0 & 41.0 & 15 & 23.4 & 8.4 & 1320 & 9.0 \\
\hline
\end{tabular}

Table 5. Fish collected from the Powder River sites in 2011. Fish IBI and O/E index scores. * $=$ species collected in 2005, but not in 2011.

\begin{tabular}{lcccccc}
\hline Powder River & Site 1 & Site 2 & Moor12 & Site 3 & Site 6 & Site 5 \\
\hline River Mile & 219 & 215.4 & 212.2 & 206.6 & 186.9 & 166.2 \\
Collection date: & $7 / 26 / 11$ & $7 / 26 / 11$ & $7 / 27 / 11$ & $7 / 27 / 11$ & $7 / 27 / 11$ & $7 / 28 / 11$ \\
\hline Channel Catfish & 3 & 2 & 1 & 4 & 0 & 1 \\
Common Carp* & 0 & 0 & 0 & 0 & 0 & 0 \\
Flathead Chub & 38 & 22 & 28 & 40 & 52 & 59 \\
Goldeye & 0 & 0 & 3 & 3 & 0 & 3 \\
Longnose Dace & 1 & 1 & 3 & 0 & 2 & 1 \\
Plains Minnow & 2 & 2 & 9 & 0 & 1 & 3 \\
Plains Killifish* & 0 & 0 & 0 & 0 & 0 & 0 \\
River Carpsucker* & 0 & 0 & 0 & 0 & 0 & 0 \\
Sand Shiner & 4 & 2 & 3 & 8 & 15 & 37 \\
Shorthead Redhorse* & 0 & 0 & 0 & 0 & 0 & 0 \\
Stonecat & 0 & 0 & 2 & 0 & 0 & 0 \\
Sturgeon Chub* & 0 & 0 & 0 & 0 & 0 & 0 \\
Western Silvery Minnow & 3 & 1 & 6 & 0 & 3 & 6 \\
\hline Total \# species & 6 & 6 & 8 & 4 & 5 & 7 \\
Native Species & 6 & 6 & 8 & 4 & 5 & 7 \\
Total Individuals & 51 & 30 & 55 & 55 & 73 & 110 \\
\hline Fish IBI & 51.9 & 53.5 & 57.6 & 53.9 & 51.4 & 57.6 \\
\hline O/E & 0.80 & 0.80 & 1.07 & 0.53 & 0.67 & 0.93 \\
\hline & & & & & &
\end{tabular}




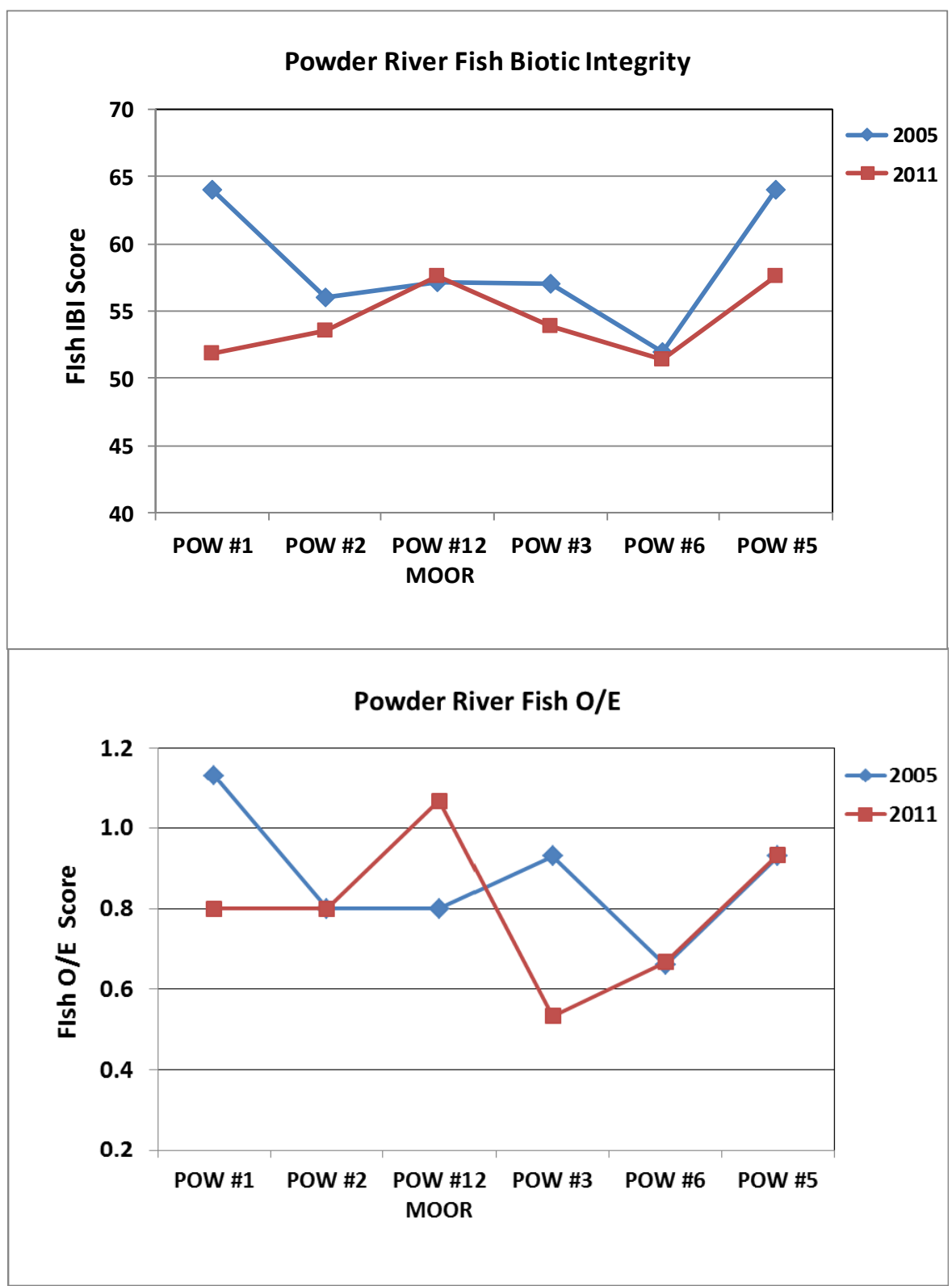

Figure 5. Powder River study reach fish community IBI (top) and Observed/ Expected (O/E) (bottom) Scores for 2005 and 2011.

Flathead chubs dominated the community composition across all sites in 2011 (avg. 66\% of individuals), representing a complete shift from the sand shiner dominated assemblages of 2005 and 2008 (Stagliano 2006, Peterson et al. 2009) (Figure 6). These data do not support the recent hypthesis that the switch in dominance to the sand shiner community was linked to a decrease in water quality. More likely, this shift was caused by spatial or temporal variability in fish communities per reach. In addition, overall decreases in the abundance of longnose dace in 2011, which are intolerant of poor water quality, lends some support to this conclusion. In contrast, an increase in the percent of western and silvery plains minnows in the catch in 2011 is a positive indicator of water quality because these species are also considered less tolerant to water quality changes, but the low numbers of total fish per site that we derived these percentages from is still troubling. 

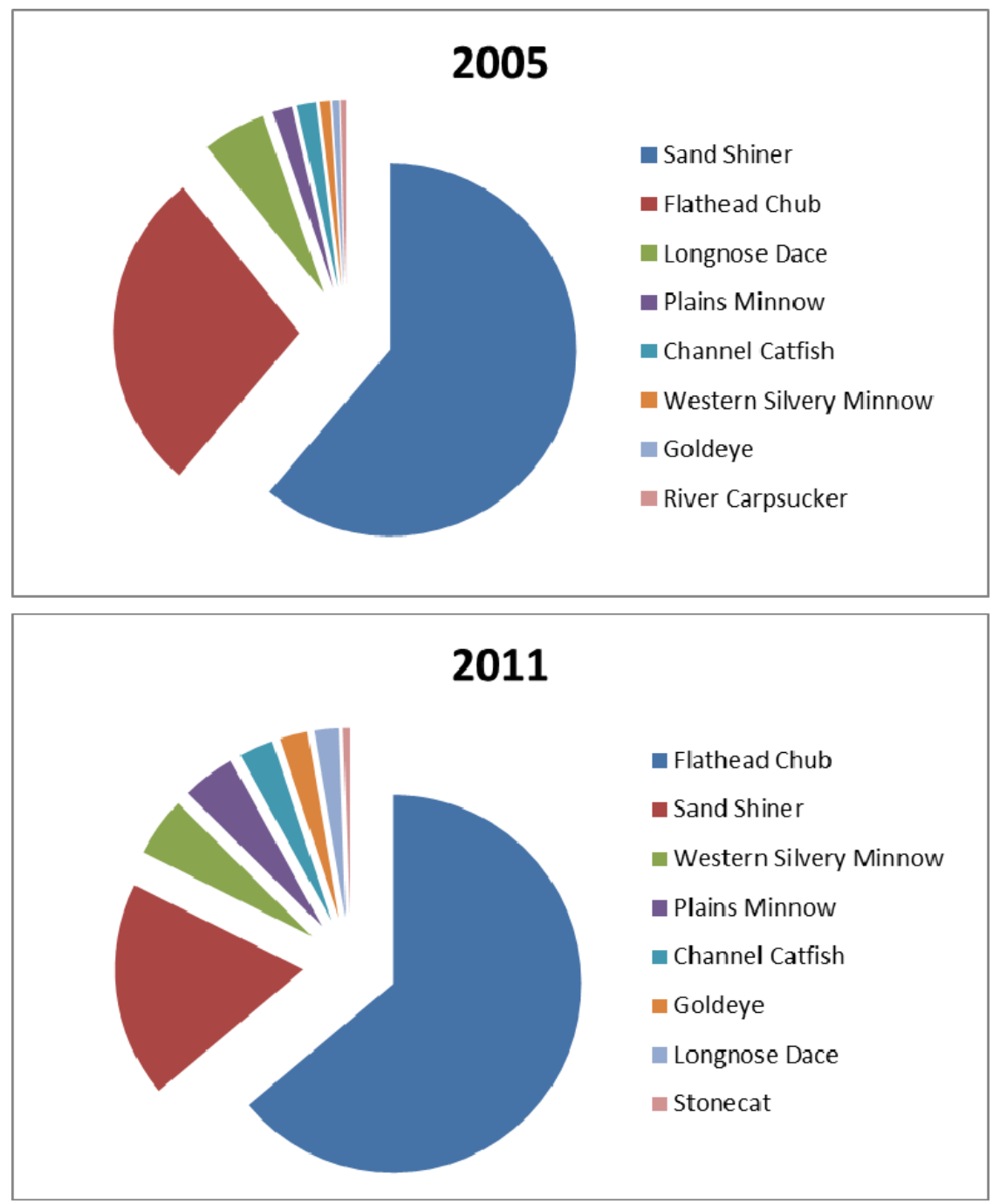

Figure 6. Powder River study reach fish community proportion for the dominant 8 species by total individuals in 2005 (top) and 20011 (bottom).

\section{Relative utility of Fish IBI vs. O/E} Although the fish IBI is inadequate to determine the fish community integrity, it is a useful tool for monitoring sites between years, and it correlated strongly with the habitat quality index $(\mathrm{r}=0.451$, $\mathrm{p}<0.05$ ). Fish IBI values ranked all Powder River sites as having fair biological integrity (scores $>25$ and $<75)$. Even when Powder River sites had their full fish community present (POW5 in 2005), they still ranked only "fair" in biointegrity with the IBI (Figure 5). This can be explained in part because the lowest-scoring metrics were those with adjustments for catchment area, such as number of native species and number of native families. The Powder River is a diverse aquatic system, but one cannot expect a linear increase in fish species with increasing watershed area. For example, to bring the IBI to over 70, a sample of all 20 native species in the Powder River with no tolerant individuals would be required. This situation brings into question the suitabilty of the IBI to a watershed of this size. The largest catchment area of sites used by Bramblett et al. (2005) in developing the fish IBI was about $14,000 \mathrm{~km}^{2}$ while catchment areas for our sites on the Powder River ranged from about $20,000 \mathrm{~km}^{2}$ to well over $23,000 \mathrm{~km}^{2}$. By extrapolating beyond the range of the calibration data, we risk serious prediction errors. By using the $\mathrm{O} / \mathrm{E}$ model as a direct measure of community completeness, the highest expected score in the 
upper Powder River reaches, despite a total species pool of approximately 20 species, is 7.5 native species.

A comparsion of diversity levels in the Powder River along the Wyoming border (POW1 at river mile 219) in 1975, 2005, and 2011 indicates that the number of native species and $\mathrm{O} / \mathrm{E}$ declined during that 36 year interval (Table 6). We can also document that the Percent Community Similarity to 1975 is very low at $24.6 \%$ (2005) and $34.6 \%$ (2011). But more surprisingly, the taxa similarity between $1975 / 2005$ and $1975 / 2011$ was $58.3 \%$ and $33.3 \%$ (respectively). Compared to sampling in 1975, of the 12 species not shared with the 1975 sample, five were collected in 2005 and eight in 2011 (Table 6). Taxa similarity between 2005 and 2011 was $62.5 \%$. In addition, two common taxa collected in 1975, lake and sturgeon chubs, which were absent from the 2005 and 2011 samples, were not observed in 2011. Moreover, sturgeon chubs have not been collected within 30 miles of this site in the past five years

\section{Macroinvertebrate Community Analysis}

Whereas 59 taxa were reported in 2005, 64 taxa were recorded in 2011 (Appendix C). Average macroinvertebrate taxa richness per site was 28.0 taxa, reflecting a significant increase from 23.4 reported in 2005 (F-test, $\mathrm{p}<0.03$ ) (Table 7). All EMAP samples agreed in ranking the six Powder River sites as non-impaired, with the DEQ MMI plains indesx score $>37$ and the OP/ $E \mathrm{p}>0$. However, the $0 / \mathrm{E} p>0.5$ scores reflect sites below the expected number of species and below the impairment threshold (Figure 7). The two protocols also yielded different community composition measures, and the within-site sampling method variability was greater than

Table 6. Powder River fish samples taken 30 and 36 years apart at the Wyoming border (POW 1). * = species not collected at this site in 2005 or 2011.

\begin{tabular}{lccc}
\hline Taxa & $\mathbf{1 0 / 1 5 / 1 9 7 5}$ & $\mathbf{7 / 1 1 / 2 0 0 5}$ & $\mathbf{7 / 2 6 / 2 0 1 1}$ \\
\hline Channel Catfish & 1 & 3 & 3 \\
Common Carp* & 4 & 0 & 0 \\
Goldeye & 10 & 3 & 0 \\
Longnose Dace & 3 & 3 & 1 \\
Flathead Chub & 965 & 96 & 38 \\
Lake Chub* & 33 & 0 & 0 \\
River Carpsucker & 3 & 1 & 0 \\
Sturgeon Chub* & 25 & 0 & 0 \\
Sand Shiner & 5 & 305 & 4 \\
Shorthead Redhorse & 7 & 1 & 0 \\
Sauger* & 1 & 0 & 0 \\
Western Silvery/Plains & 0 & 12 & 5 \\
Minnow & & $\mathbf{8}$ & $\mathbf{6}$ \\
Total Native Species & $\mathbf{1 0}$ & $\mathbf{1 . 1 3}$ & $\mathbf{0 . 8 0}$ \\
\hline O/E & $\mathbf{1 . 2 7}$ & $\mathbf{2 4 . 6 \%}$ & $\mathbf{3 4 . 6 \%}$ \\
\hline \% Community Similarity & & $\mathbf{5 8 . 3 \%}$ & $\mathbf{2 0 0 5 - 6 2 . 5 \%}$ \\
\hline Taxa Similarity & & & $\mathbf{1 9 7 5 - 3 3 . 3 \%}$ \\
\hline
\end{tabular}


similar-method across site variability. The number of individuals obtained in a targeted riffle (TR) sample was significantly higher than the reachwide (RW) EMAP samples (F-test, $\mathrm{p}<0.001$ ). All TR samples had to be sub-sampled to reduce the number of organisms for the targeted 600 count, whereas three of the RW samples failed to reach 600 organisms after picking $100 \%$ of the sample (Table 7).

Reach-Wide EMAP samples did collect two of the five species of rare sand-dwelling mayflies, Anepeorus rusticus (G2S1) and Homoeoneuria alleni (G4S2), which were not sampled with the Targeted-Riffle Protocols (Table 8). The number of sites where four SOC taxa were collected has increased by ten since 2005 . They were not detected at only four sites where they had been encountered in 2005 (Table 8). Unfortunately for one SOC mayfly taxon, Raptoheptagenia cruentata, significant population declines are occurring despite only being "lost" from one site in 2011 (Figure 7, Table 8). In contrast, one of only two stonefly species, Acroneuria abnormis, has increased in both population density and site occupancy from 2005 to 2011 (Figure 7).

Six other "sensitive" taxa followed similar trends of being detected at more sites in 2011 than being lost (not detected) from sites occupied in 2005 , including new "additions" to the study reach by a stonefly taxon, Isoperla, and a sensitive Tipulid dipteran (Table 8). Extensive time/distance sampling of sandbar habitat at three sites did not add any additional SOC taxa to the species list or obtain sufficient numbers of individuals to estimate densities per area of stream bottom (Table 9). These sandbar taxa are truly rare with randomized clumped distributions, making it even harder to estimate population size or densities per unit river bottom. However, randomization of the EMAP RW sampling scheme (right, left, center) appeared to provide a reasonably good probablity of detection, as addtional taxa were not found at the three sandbar sites where extensive sampling occurred (Table 9).

Previous investigations from 1999 through 2002 by Dan Gustafson (pers. comm., 2006) and a subsequent study (Staligano 2006) suggest the mayflies are not only rare, but may been already

Table 7. EMAP macroinvertebrate results: T $R=$ Targeted Riffle, $R W=$ Reach-wide. $\%$ Sub=percent of sample picked, \#Ind= number of individuals picked from subsample. EPT=Ephemeroptera, Plecoptera, and Trichoptera taxa in sample, TTaxa= total taxa richness, number of individuals in the sample, multimetric index score, and aquatic impairment status for stream site.

\begin{tabular}{llccccccc}
\hline \multicolumn{1}{c}{ Site } & Site_code & $\begin{array}{c}\text { EMAP } \\
\text { Method }\end{array}$ & $\begin{array}{c}\text { \% Sub } \\
\text { Picked }\end{array}$ & \# Ind & TTaxa & $\begin{array}{c}\text { EPT } \\
\text { Taxa }\end{array}$ & MMI & Status \\
\hline Powder River 1 & YL_SPW1 & TR-500 & 25 & 632 & 26 & 21 & 53.5 & Non-Impaired \\
Powder River 1 & YL_SPW1Q & RW-500 & 100 & 561 & 37 & 25 & 49.6 & Non-Impaired \\
Powder River 2 & YL_SPW2 & TR-500 & 50 & 629 & 26 & 17 & 56.0 & Non-Impaired \\
Powder River 2 & YL_SPW2Q & RW-500 & 100 & 618 & 34 & 21 & 51.4 & Non-Impaired \\
Powder River & YL_SPWM & TR-500 & 25 & 603 & 28 & 18 & 56.9 & Non-Impaired \\
Moorhead & & & & & & & & \\
Powder River & YL_SPWMQ & RW-500 & 50 & 607 & 31 & 18 & 51.4 & Non-Impaired \\
Moorhead & & & & & & & & \\
Powder River 3 & YL_SPW3 & TR-500 & 33.3 & 558 & 28 & 19 & 59.1 & Non-Impaired \\
Powder River 3 & YL_SPW3Q & RW-500 & 100 & 385 & 25 & 16 & 46.1 & Non-Impaired \\
Powder River 6 & YL_SPW6 & TR-500 & 50 & 631 & 26 & 17 & 54.5 & Non-Impaired \\
Powder River 6 & YL_SPW6Q & RW-500 & 50 & 603 & 28 & 17 & 51.9 & Non-Impaired \\
Powder River 5 & YL_SPW5 & TR-500 & 50 & 603 & 25 & 17 & 58.7 & Non-Impaired \\
Powder River 5 & YL_SPW5Q & RW-500 & 100 & 394 & 22 & 13 & 46.5 & Non-Impaired \\
\hline
\end{tabular}


Table 8. Sensitive and SOC macroinvertebrate species site occupancy changes from 2005-2011: X= collected during both years; (+) = detected in 2011, but not in 2005; (-) = detected in 2005, but not in 2011; blank = not collected at site. TolVal = MT DEQ Tolerance Rank (0, most sensitive), NS Rank = NatureServe Conservation Ranks (see Appendix A).

\begin{tabular}{|c|c|c|c|c|c|c|c|c|c|}
\hline Sensitive Species & $\begin{array}{r}\text { Tol. } \\
\text { Value } \\
\end{array}$ & $\begin{array}{c}\text { MT } \\
\text { SOC }\end{array}$ & $\begin{array}{c}\text { NS } \\
\text { Rank } \\
\end{array}$ & POW1 & POW2 & $\begin{array}{l}\text { POW } \\
\text { Moor } \\
\end{array}$ & POW3 & POW6 & POW5 \\
\hline Acroneuria abnormis $(\mathrm{P})$ & 0 & & & $\mathrm{X}$ & $\mathrm{X}$ & $\mathrm{X}$ & $(+)$ & $\mathrm{X}$ & $\mathrm{X}$ \\
\hline Anepeorus rusticus (E) & 1 & $\mathrm{x}$ & $\mathrm{G} 2 \mathrm{~S} 1$ & $(+)$ & $(-)$ & & & & $(+)$ \\
\hline Brachycentrus occidentalis $(\mathrm{T})$ & 1 & & & $\mathrm{X}$ & $\mathrm{X}$ & $\mathrm{X}$ & $(+)$ & $\mathrm{X}$ & $(+)$ \\
\hline Dicranota (D) & 0 & & & $(+)$ & $(+)$ & & & & \\
\hline Leucrocuta (E) & 1 & & & $\mathrm{X}$ & $\mathrm{X}$ & $\mathrm{X}$ & $\mathrm{X}$ & $(+)$ & $\mathrm{X}$ \\
\hline Homoeoneuria alleni $(\mathrm{E})$ & 2 & $\mathrm{x}$ & G4S2 & & $\mathrm{X}$ & $(+)$ & $(+)$ & $(+)$ & $\mathrm{X}$ \\
\hline Isoperla $(\mathrm{P})$ & 2 & & & & & & $(+)$ & $(+)$ & \\
\hline Raptoheptagenia cruentata*(E) & 1 & $\mathrm{x}$ & G4S2 & $\mathrm{X}$ & $\mathrm{X}$ & & $\mathrm{X}$ & $\mathrm{X}$ & $(-)$ \\
\hline Rhithrogena (E) & 0 & & & $(+)$ & $(+)$ & $\mathrm{X}$ & $(+)$ & $(+)$ & \\
\hline Stylurus intricatus $(\mathrm{O})$ & 2 & $\mathrm{x}$ & G4S1 & $(-)$ & $(-)$ & $(+)$ & & $\mathrm{X}$ & \\
\hline
\end{tabular}

Table 9. Number of sand-dwelling SOC individuals collected with the EMAP Reach-wide (RW) vs. Sandbar Timed Kick (SB Kick) at three sites with sampling effort. * = not an SOC, but collected with both sampling methods.

\begin{tabular}{|c|c|c|c|c|c|c|}
\hline \multirow[b]{2}{*}{ SOC Species } & \multicolumn{2}{|c|}{ POW Moorhead } & \multicolumn{2}{|c|}{ POW3 } & \multicolumn{2}{|c|}{ POW6 } \\
\hline & $\begin{array}{l}\text { EMAP RW } \\
0.93 \mathrm{~m}^{2}\end{array}$ & $\begin{array}{l}\text { SB Kick } \\
3.0 \mathrm{~m}^{2}\end{array}$ & $\begin{array}{r}\text { EMAP RW } \\
0.93 \text { m }^{2}\end{array}$ & $\begin{array}{c}\text { SB Kick } \\
3.5 \mathrm{~m}^{2}\end{array}$ & \begin{tabular}{|c} 
EMAP RW \\
0.93 m $^{2}$
\end{tabular} & $\begin{array}{c}\text { SB Kick } \\
6.0 \mathrm{~m}^{2}\end{array}$ \\
\hline Anepeorus rusticus (E) & 0 & 0 & 0 & 0 & 0 & 0 \\
\hline Analetris eximia (E) & 0 & 0 & 0 & 0 & 0 & 0 \\
\hline Homoeoneuria alleni (E) & 1 & 2 & 3 & 1 & 19 & 5 \\
\hline Lachlania saskatchewanensis $^{1}(\mathrm{E})$ & 0 & 0 & 0 & 0 & 0 & 0 \\
\hline Ophiogomphus severus* $(\mathrm{O})$ & 4 & 3 & 1 & 4 & 3 & 1 \\
\hline Stylurus intricatus $(\mathrm{O})$ & 1 & 1 & 0 & 0 & 1 & 2 \\
\hline
\end{tabular}

${ }^{1}$ Potential Species of Concern 


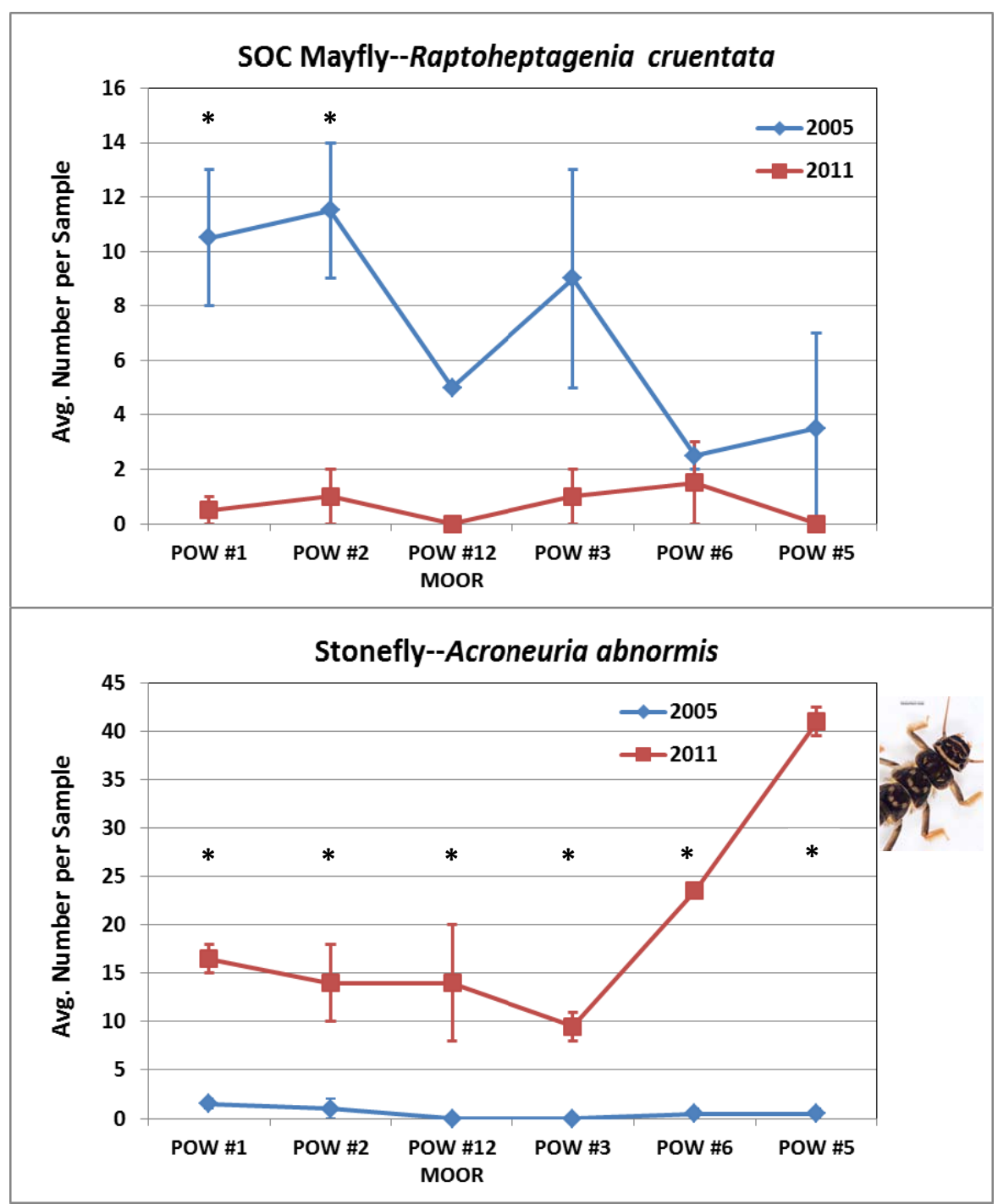

Figure 7. Individual species responses across sites and years of the SOC mayfly (top) and golden stonefly (bottom). * = significant difference between years ( $t$-test, $p<0.05)$. Bars reflected indicate 1 standard error.

in serious decline. These species once may have been quite common in prairie rivers across the northern Great Plains, but have been eliminated throughout most of their historic range due to impoundments and other anthropogenic river alterations. Unfortunately, inadequate pre-CBNG baseline data on sand-dwelling invertebrates in the Powder River following standardized bioassessment sampling (response of J. Frelich to Powder River EIS [Stagliano 2006]), prevents knowing more accurately the long-term trends of specialized mayflies (Stagliano 2006, Petersen et al. 2010). Although we targeted these species in 2011 with specialized collecting techniques to serve as baseline population estimates for future monitoring, the current absence of many taxa collected previously throughout the study reach suggests that options for helping to conserve the species may be limited.

\section{Macroinvertebrate IBI vs. O/E}

No discernible trends were evident in macroinvertebrate $\mathrm{MMI}$ index or $\mathrm{O} / \mathrm{E}_{\mathrm{p}>0.5}$ scores from the Wyoming Border to Broadus (Figure 8) and MMI scores in 2011 were not significantly different from 2005 (F-test, $\mathrm{p}>0.05$ ) (Figure 8). Proceeding downstream the $\mathrm{O} / \mathrm{E} \mathrm{p}>0$ had a slight 
decreasing trend and showed more variability in the upper sites by the Wyoming border (Figure 8). As measured by the MTDEQ plains MMI and $\mathrm{O} / \mathrm{E}$ model in 2011, the biological condition for all assessed Powder River sites, except POW5Q $(\mathrm{O} / \mathrm{E})$, was nonimpaired, as it was in 2005 (Figure 8 ). However, as measured by the $\mathrm{O} / \mathrm{E} \mathrm{p}>0.5$, all samples fell below the impairment threshold, indicating a signficant departure (i.e., taxa loss or replacement) from expected biological community conditions (Figure 8). But when applying the $\mathrm{O} / \mathrm{E}_{\mathrm{p}>0.5}$ all samples fall below the impairment threshold indicating a significant departure (ie. taxa loss or replacement) from expected biological community conditions (Figure 8). Selected site patterns in biological condition observed in 2005 were repeated in 2011 with appreciable increases in the MMI scores at sites POW2 and POWMOOR and decreases in integrity at POW1 and POW5 (Figure 8).

Although all sites ranked unimpaired with MMI, there was a ca. 20-point scoring spread between the lowest MMI score of 46.5 (2011, POW5 RW) and 65.4 (2005, POW5 RW). Thus, site POW5 (RW) had the most severe macrinvertebrate community integrity decline between years, although it should be noted that RW samples are always more variable than targeted Riffles (Figure 8).

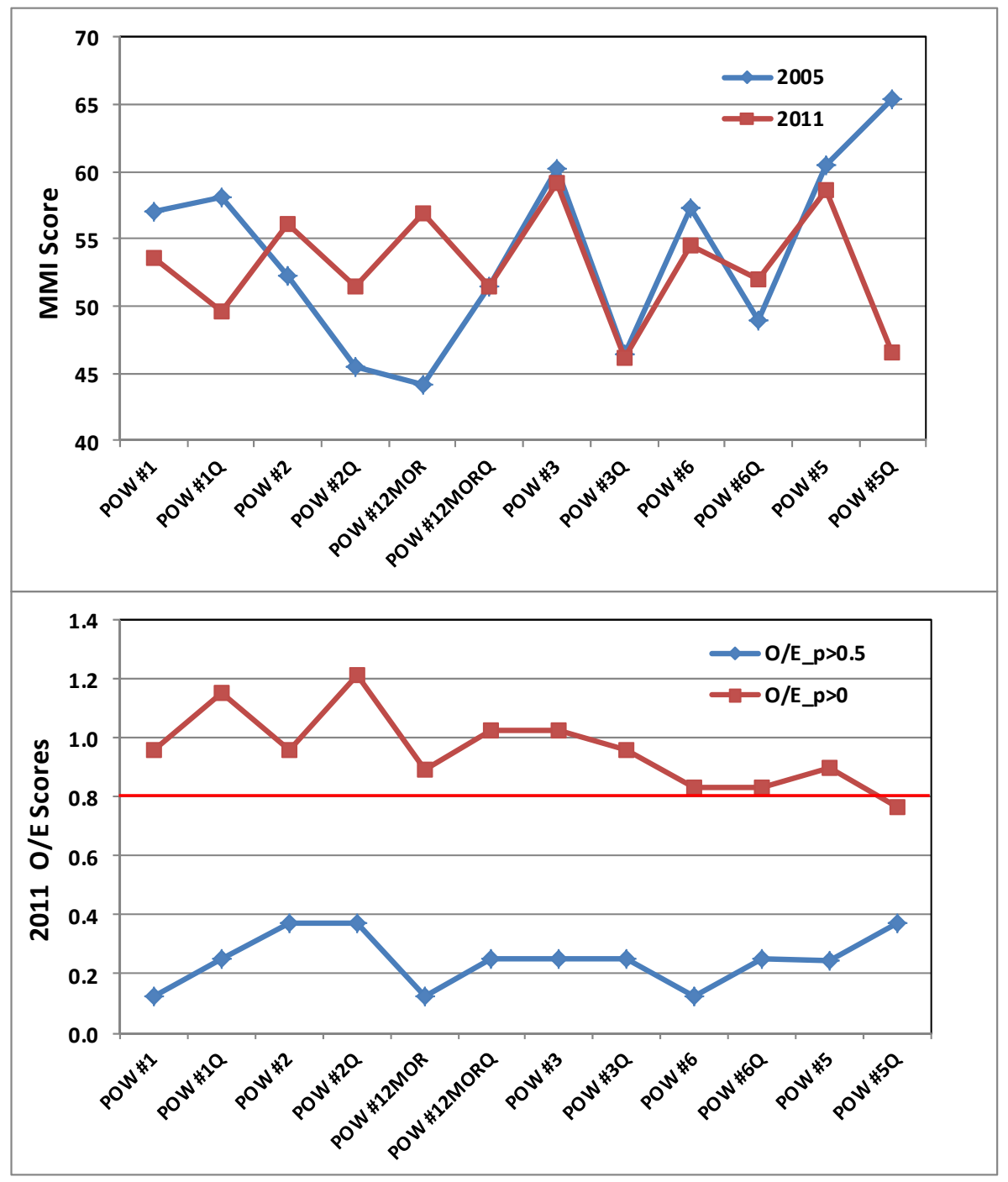

Figure 8. Powder River study reach macroinvertebrate MMI for 2005 and 2011 (top) and Observed/Expected (O/E $p>0, O / E p>0.5$ ) Scores for 2011 (bottom). Horizontal red line is the impairment threshold. 


\section{Conclusions and Recommendations}

The following conclusions and recommendations are offered based on results from surveys:

1. All study sites in the Powder River ranked unimpaired with the DEQ MMI and O/E $\mathrm{p}>0$, but by incorporating the fish IBI, O/E, macroinvertebrate $\mathrm{O} / \mathrm{E}_{\mathrm{p}>0.5}$ and individual sensitive species responses, a clearer picture of biological integrity is probably realized. Fish $\mathrm{O} / \mathrm{E}$ analysis ranked Sites 3 and 6 as biologically impaired and Site 1 was on the impairment threshold with greatly reduced scores compared to 2005. Community Integrity results from the 2011 fish and macroinvertebrate surveys combined to rank the Powder River reach at the Moorhead Bridge Site as the most biologically intact, followed by Powder River Site 5 upstream of Rough Creek.

2. Results from macroinvertebrate samples demonstrated that the EMAP Targeted Riffle protocols sample more insects, track the fish $\mathrm{O} / \mathrm{E}$ more closely, and have less variability when applied in the field compared to other protocols. Therefore, we recommend replicated EMAP Targeted-Riffle Protocols for future monitoring efforts, while continuing to evaluate multi-habitat protocols, such as the EMAP reach-wide for collecting the rare, SOC sand-dwelling group.
3. The fish community at the Wyoming border has changed significantly over the past three decades, and continues to lose sensitive species and biological integrity. For example, sturgeon chubs have significantly declined or are now absent in the study reach from the Wyoming Border to Moorhead Bridge and potentially further downstream. Patton et al. (1998) found sturgeon chubs at half of the eight sites sampled in the Wyoming portions of the Powder River near Montana. Confluence Consulting (2004) found two sturgeon chubs in 2002 at only one Wyoming site close to the Montana border, and three years later MTNHP (Stagliano 2006) and the USGS (2005) did not capture a single sturgeon chub within 40 miles of the Wyoming border despite combined sampling of 6 stream reaches. The rarity of the sturgeon chub in this reach is alarming for a river that has provided substantial habitat for this species in the past. We recommend additional fish surveys downstream near Broadus to find the new upstream distributional extent of this species. Additional studies that test the tolerance to water chemistry changes in sturgeon chub and other native fish species could be a component of futuring monitoring for CBNG development in the Powder River basin. 


\section{Literature Cited}

Barbour, M., J. Gerritsen, B.D. Snyder, and J.B. 1999. Rapid Bioassessment Protocols for Use in Streams and Wadable Rivers: Periphyton, Benthic Macroinvertebrates and Fish, Second Edition. EPA 841-B-99-002. United States Environmental Protection Agency; Office of Water: Washington, D.C.

Baxter, G.T. and M.D. Stone. 1995. Fishes of Wyoming. Wyoming Game and Fish Department, Cheyenne, WY.

Becker, G. C. 1983. Fishes of Wisconsin. University of Wisconsin Press, Madison

Bramblett, R.G., T.R. Johnson, A.V. Zale, and D. Heggem. 2005. Development and evaluation of a fish assemblage index of biotic integrity for northwestern great plains. Transactions of the American Fisheries Society 134:624-640.

Brower, J.E. and J.H. Zar. 1984. Field and Laboratory Methods for General Ecology (2nd Ed.). Wm. C. Brown Publishers. Dubuque, IA.

Brown, C. J. D. 1971. Fishes of Montana. Big Sky Books, Montana State University, Bozeman.

Confluence Consulting. 2004. Powder River Biological Survey and Implications for Coalbed Methane Development. Prepared for Powder River Basin Resource Council. 67 pp. + appendices.

Davis, W. and B. Bramblett. 2006. Effects of Coalbed Natural Gas Development on Fish Assemblages in the Powder River Basin. Montana Cooperative Fishery Research Unit Fact Sheet, Montana State University. 3pp.

Dodds, W.K., K. Gido, M.R. Whiles, K.M. Fritz, and W. J. Matthews. 2004. Life on the edge: The ecology of Great Plains prairie streams. BioScience 54: 205-216.
Feldman, D. 2006. Interpretation of New Macroinvertebrate Models by WQPB. Draft Report. Montana Department of Environmental Quality, Planning Prevention and Assistance Division, Water Quality Planning Bureau, Water Quality Standards Section. 1520 E. 6th Avenue, Helena, MT 59620. 14 pp.

Holton, G.D. and H.E. Johnson. 2003. A field guide to Montana fishes, 3rd edition. Montana Fish, Wildlife, and Parks, Helena.

Hubert, W.A. 1993. The Powder River: a relatively pristine stream on the Great Plains. In: Restoration Planning for Rivers of the Mississippi Ecosystem. US National Biological Survey Biological Report 19.

Jessup, B., J. Stribling, and C. Hawkins. 2005. Biological indicators of stream condition in Montana using macroinvertebrates. Tetra Tech, Inc. Report to MT DEQ.

Lazorchak, J.M., D.J. Klemm, and D.V. Peck (editors). 1998. Environmental Monitoring and Assessment Program - Surface Waters: Field Operations and Methods for Measuring the Ecological Condition of Wadeable Streams. EPA/620/R-94/004F. U.S. Environmental Protection Agency, Washington, D.C.

Marchant, R. 2002. Do rare species have any place in multivariate analysis for bioassessment? Journal of the NA Benthological Society 21:311313.

MTNHP and MTFWP 2006. Montana Natural Heritage Program and Montana Fish Wildlife and Parks. Montana animal species of concern. Helena, MT: MTNHP and MTFWP 11p.http:// mtnhp.org/Reports/2006_MASOC.pdf

Patton, T.M, F.J. Rahel, and W.A. Hubert. 1998. Using historical data to assess changes in Wyoming's fish fauna. Conservation Biology 12:1120-1128. 
Peck, D.V., J.M. Lazorchak, and D.J. Klemm (eds.), 2003. Environmental Monitoring and Assessment Program - surface waters: Western Pilot Study field operations manual for wadeable streams: Washington, D.C., U.S. Environmental Protection Agency, 258 pp.

Peterson, D.A., M.L. Clark, K. Foster, P.R. Wright, and G.K. Boughton. 2010. Assessment of ecological conditions and potential effects of water produced from coalbed natural gas development on biological communities in streams of the Powder River structural basin, Wyoming and Montana, 2005-08: U.S. Geological Survey Scientific Investigations Report 2010-5124, 84 pp.

Peterson, D.A., E.G. Hargett, and D.L. Feldman. 2011. Assessment of potential effects of water produced from coalbed natural gas development on macroinvertebrate and algal communities in the Powder River and Tongue River, Wyoming and Montana, 2010: U.S. Geological Survey Open-File Report 2011-1294, 34 pp.

Pflieger, W. L. 1997. The fishes of Missouri, revised edition. Missouri Department of Conservation, Jefferson City.

Rehwinkel, B.J. 1978. Powder River aquatic ecology report. Report prepared for Utah International, Inc. Montana Department of Fish and Game.

Scott, W. B., and E. J. Crossman. 1973. Freshwater fishes of Canada. Fisheries Research Board of Canada, Bulletin 184, Ottawa

Stagliano, D.M. and W.M. Gould. 2010. Montana AFS Species of Special Concern Status Pages. http://www.fisheries.org/units/AFSmontana/ SturgeonChub.html
Stagliano, D.M. 2005. Aquatic Community Classification and Ecosystem Diversity in Montana's Missouri River Watershed. Report to the Bureau of Land Management. Montana Natural Heritage Program, Helena, MT. 65 pp. plus appendices. http://mtnhp.org/Reports. asp?key $=1$

Stagliano, D. 2006. Aquatic surveys and assessment within the Middle Powder River watershed: Report to the U.S. Bureau of Land Management (ESA010009), 37 pp. http://mtnhp. org/Reports/Mid_Powd_Riv_Water_Assess.pdf

Vance, L., D. Stagliano, and G.M. Kudray. 2006. Watershed Assessment of the Middle Powder Subbasin, Montana. A report to the Bureau of Land Management, Montana State Office. Montana Natural Heritage Program, Helena, MT. 61 pp. plus appendices.

Werdon, S.J. 1992. Population status and characteristics of Macrhybopsis gelida, Platygobio gracilis and Rhinichthys cataractae in the Missouri River Basin. South Dakota State University, Brookings, SD. M.S. Thesis, 55pp. 

Appendix A. Global/State Rank Definitions 



\section{Heritage Program Ranks}

The international network of Natural Heritage Programs employs a standardized ranking system to denote global (range-wide) and state status. Species are assigned numeric ranks ranging from 1 to 5 , reflecting the relative degree to which they are "at-risk". Rank definitions are given below. A number of factors are considered in assigning ranks - the number, size and distribution of known "occurrences" or populations, population trends (if known), habitat sensitivity, and threat. Factors in a species' life history that make it especially vulnerable are also considered (e.g., dependence on a specific pollinator).

Global Rank Definitions (NatureServe 2003)

G1 Critically imperiled because of extreme rarity and/or other factors making it highly vulnerable to extinction

G2 Imperiled because of rarity and/or other factors making it vulnerable to extinction

G3 Vulnerable because of rarity or restricted range and/or other factors, even though it may be abundant at some of its locations

G4 Apparently secure, though it may be quite rare in parts of its range, especially at the periphery

G5 Demonstrably secure, though it may be quite rare in parts of its range, especially at the periphery

T1-5 Infraspecific Taxon (trinomial) - The status of infraspecific taxa (subspecies or varieties) are indicated by a "T-rank" following the species' global rank

\section{State Rank Definitions}

S1

S2

S3

S4

S5

At high risk because of extremely limited and potentially declining numbers, extent and/or habitat, making it highly vulnerable to extirpation in the state At risk because of very limited and potentially declining numbers, extent and/or habitat, making it vulnerable to extirpation in the state

S3 Potentially at risk because of limited and potentially declining numbers, extent and/or habitat, even though it may be abundant in some areas

S4 Uncommon but not rare (although it may be rare in parts of its range), and usually widespread. Apparently not vulnerable in most of its range, but possibly cause for long-term concern Common, widespread, and abundant (although it may be rare in parts of its range). Not vulnerable in most of its range

\section{Combination Ranks}

G\#G\# or S\#S\# Range Rank-A numeric range rank (e.g., G2G3) used to indicate uncertainty about the exact status of a taxon

\section{QuALIFIERS}

NR Not ranked


X

no

H

U

HYB

$?$

C tion,

A

Z

P

R

SYN

$*$

B

Presumed Extinct - Species believed to be extinct throughout its range. Not located despite intensive searches of historical sites and other appropriate habitat, and virtually

likelihood that it will be rediscovered

Possibly Extinct - Species known from only historical occurrences, but may never-theless still be extant; further searching needed

Unrankable - Species currently unrankable due to lack of information or due to substantially conflicting information about status or trends

Hybrid-Entity not ranked because it represents an interspecific hybrid and not a species

Inexact Numeric Rank-Denotes inexact numeric rank

Captive or Cultivated Only_-Species at present is extant only in captivity or cultiva-

or as a reintroduced population not yet established

Accidental-Species is accidental or casual in Montana, in other words, infrequent and outside usual range. Includes species (usually birds or butterflies) recorded once or only a few times at a location. A few of these species may have bred on the one or two occasions they were recorded

Zero Occurrences - Species is present but lacking practical conservation concern in Montana because there are no definable occurrences, although the taxon is native and appears regularly in Montana

Potential-Potential that species occurs in Montana but no extant or historic occurrences are accepted

Reported-Species reported in Montana but without a basis for either accepting or rejecting the report, or the report not yet reviewed locally. Some of these are very recent discoveries for which the program has not yet received first-hand information; others are old, obscure reports

Synonym - Species reported as occurring in Montana, but the Montana Natural Heritage Program does not recognize the taxon; therefore the species is not assigned a rank

A rank has been assigned and is under review. Contact the Montana Natural Heritage Program for assigned rank

Breeding - Rank refers to the breeding population of the species in Montana

Appendix A - 2 


\section{Appendix B. RaW fish data ANd IBI metric Calculations FROM PoWder River SITES.}





\begin{tabular}{|c|c|c|c|c|c|c|c|c|c|c|c|c|}
\hline \multirow{2}{*}{$\frac{\text { Fish Species }}{\text { Channel Catfish }}$} & \multicolumn{2}{|c|}{ Powder River \#1 } & \multicolumn{2}{|c|}{ Powder River \#2 } & \multicolumn{2}{|c|}{$\begin{array}{l}\text { Powder River } \\
\text { \#Moorhead }\end{array}$} & \multicolumn{2}{|c|}{ Powder River \#3 } & \multicolumn{2}{|c|}{ Powder River \#6 } & \multicolumn{2}{|c|}{ Powder River \#5 } \\
\hline & 3 & & 2 & & 1 & & 4 & & 0 & & 1 & $T$ \\
\hline Flathead Chub & 38 & & 22 & & 28 & & 40 & & 52 & & 59 & \\
\hline Goldeye & 0 & & 0 & & 3 & & 3 & & 0 & & 3 & 3 \\
\hline Longnose Dace & 1 & & 1 & & 3 & & 0 & & 2 & & 1 & 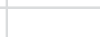 \\
\hline Plains Minnow & 2 & & 2 & & 9 & & 0 & & 1 & & 3 & 3 \\
\hline Sand Shiner & 4 & & 2 & & 3 & & 8 & & 15 & & 37 & \\
\hline Stonecat & 0 & & 0 & & 2 & & 0 & & 0 & & 0 & \\
\hline Western Silvery Minnow & 3 & & 1 & & 6 & & 0 & & 3 & & 6 & ; \\
\hline Total \# species & 6 & & 6 & & 8 & & 4 & & 5 & & 7 & \\
\hline Native Species & 6 & & 6 & & 8 & & 4 & & 5 & & 7 & \\
\hline Native Families & 2 & & 2 & & 3 & & 3 & & 1 & & 3 & 3 \\
\hline Total Individuals & 51 & & 30 & & 55 & & 55 & & 73 & & 110 & \\
\hline \# Minnow Species Thrive & 4 & & 4 & & 5 & & 2 & & 4 & & 5 & 5 \\
\hline Proportion of tolerant individuals & 0.00 & & 0.00 & & 0.00 & & 0.00 & & 0.00 & & 0.00 & \\
\hline \# Sucker + Catfish Species & 1 & & 1 & & 2 & & 1 & & 0 & & 1 & 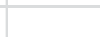 \\
\hline$\%$ Insectivorous Minnows & 76.47 & & 76.67 & & 61.82 & & 78.18 & & 73.97 & & 57.27 & \\
\hline \# Benthic Invertivore Species & 1 & & 2 & & 1 & & 1 & & 1 & & 1 & 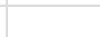 \\
\hline \% Litholphilic Spawners & 9.80 & & 10.00 & & 20.00 & & 20.00 & & 23.29 & & 37.27 & \\
\hline$\%$ Parental Care & 5.88 & & 6.67 & & 1.82 & & 7.27 & & 0.00 & & 0.91 & \\
\hline$\%$ Native to Montana & 100.00 & & 100.00 & & 100.00 & & 100.00 & & 100.00 & & 100.00 & \\
\hline \# Long Lived Species & 4 & & 4 & & 6 & & 4 & & 5 & & 6 & ; \\
\hline Metrics & $\begin{array}{l}\text { Adjust } \\
\text { Value }\end{array}$ & Score & $\begin{array}{l}\text { Adjust } \\
\text { Value }\end{array}$ & Score & $\begin{array}{l}\text { Adjust } \\
\text { Value }\end{array}$ & Score & $\begin{array}{l}\text { Adjust } \\
\text { Value }\end{array}$ & Score & $\begin{array}{l}\text { Adjust } \\
\text { Value }\end{array}$ & Score & $\begin{array}{l}\text { Adjust } \\
\text { Value }\end{array}$ & Score \\
\hline Number of Native Fish Species & 4.86 & 27.00 & 4.86 & 27.00 & 6.86 & 38.11 & 2.86 & 15.89 & 3.86 & 21.44 & 5.86 & 32.55 \\
\hline Number of Native Fish Families & 1.83 & 33.68 & 1.83 & 33.68 & 2.83 & 52.12 & 2.83 & 52.12 & 0.83 & 15.24 & 2.83 & 52.12 \\
\hline Proportion of tolerant individuals & 0.00 & 100.00 & 0.00 & 100.00 & 0.00 & 100.00 & 0.00 & 100.00 & 0.00 & 100.00 & 0.00 & 100.00 \\
\hline \# of Sucker and Catfish Species & 0.42 & 4.62 & 0.42 & 4.62 & 1.42 & 15.49 & 0.42 & 4.62 & -0.58 & -6.25 & 0.42 & 4.62 \\
\hline $\begin{array}{l}\text { Proportion out of the Total } \\
\text { Number of Fish That Were Insect } \\
\text { eating Minnows }\end{array}$ & 76.47 & 105.02 & 76.67 & 105.29 & 61.82 & 84.90 & 78.18 & 107.37 & 73.97 & 101.59 & 57.27 & 78.66 \\
\hline $\begin{array}{l}\text { Total Number of Species That } \\
\text { Prefer to Eat Insects That Live on } \\
\text { the Stream Bottom }\end{array}$ & 0.56 & 9.45 & 1.56 & 26.45 & 0.56 & 9.45 & 0.56 & 9.45 & 0.56 & 9.45 & 0.56 & 9.45 \\
\hline $\begin{array}{l}\text { Proportion of the Total Number of } \\
\text { Fish That Require Rocks to Lay } \\
\text { Eggs }\end{array}$ & 9.80 & 11.82 & 10.00 & 12.06 & 20.00 & 24.12 & 20.00 & 24.12 & 23.29 & 28.08 & 37.27 & 44.94 \\
\hline $\begin{array}{l}\text { Proportion of the Total Number of } \\
\text { Individuals That Do Not Require } \\
\text { Rocks, But Have Parental Care of } \\
\text { Eggs }\end{array}$ & 5.88 & 93.31 & 6.67 & 92.42 & 1.82 & 97.93 & 7.27 & 91.73 & 0.00 & 100.00 & 0.91 & 98.97 \\
\hline $\begin{array}{l}\text { Proportion of the Total Number of } \\
\text { Fish Sampled That Are Native }\end{array}$ & 100.00 & 100.04 & 100.00 & 100.04 & 100.00 & 100.04 & 100.00 & 100.04 & 100.00 & 100.04 & 100.00 & 100.04 \\
\hline $\begin{array}{l}\text { Number of Long-Lived Native } \\
\text { Species }\end{array}$ & 3.31 & 33.92 & 3.31 & 33.92 & 5.31 & 54.41 & 3.31 & 33.92 & 4.31 & 44.16 & 5.31 & 54.41 \\
\hline Sum of Metrics & & 518.86 & & 535.47 & & 576.55 & & 539.25 & & 513.75 & & 575.75 \\
\hline IBI Score & & 51.89 & & 53.55 & & 57.66 & & 53.92 & & 51.38 & & 57.57 \\
\hline
\end{tabular}



Appendix C. Macroinvertebrate taxa lists, abundance, And PLAINS MMI CALCULATIONS AT EACH SITE. 



\section{Montana Bioassessment Report}

Waterbody Name: Powder River@WYBorder Station ID: YLPOW1t1

Reference

STORET Activity ID:

Rep.

Site Classification:

Collection Date:

P1-R500-M

Latitude:

Collection Method:

$07 / 26 / 2011$

Longitude:

Total Number of Individuals in Sample:

632

\section{Sample Taxa List}

\begin{tabular}{|c|c|c|c|c|c|c|}
\hline Order: & OTU name: & FinalID: & ndividuals & Tol Val: & $F F G_{:}$ & Habit: \\
\hline Coleoptera & Microcylloepus & Microcylloepus pusillus & 15 & 5 & CG & "CN/50\%, BU/50\%" \\
\hline Coleoptera & Stenelmis & Stenelmis & 3 & 5 & SC/CG & "CN/50\%, BU/50\%" \\
\hline Diptera & Chironominae & Cryptochironomus & 2 & 7 & CG/CF/PR & $\mathrm{BU} / \mathrm{CN} / \mathrm{SP}$ \\
\hline Diptera & Chironominae & Robackia & 1 & 7 & CG/CF/PR & $\mathrm{BU} / \mathrm{CN} / \mathrm{SP}$ \\
\hline Diptera & Hemerodromia & Hemerodromia & 1 & 6 & PR & SP \\
\hline Diptera & Simuliidae & Simulium & 244 & 6 & CF & $\mathrm{CN}$ \\
\hline Ephemeropte & r Acentrella & Acentrella turbida & 3 & 4 & CG & "SW/10\%, CN/90\%" \\
\hline Ephemeropte & r Baetis & Baetis intercalaris & 4 & 5 & CG & "SW/10\%, CN/90\%" \\
\hline $\begin{array}{l}\text { Ephemeropte } \\
\text { Ephemeropte }\end{array}$ & $\begin{array}{l}\text { r Camelobaetidius } \\
\text { er Cercobrachys }\end{array}$ & $\begin{array}{l}\text { Camelobaetidius warreni } \\
\text { Cercobrachys cree }\end{array}$ & $\begin{array}{l}2 \\
3\end{array}$ & $\begin{array}{l}4 \\
4\end{array}$ & $\begin{array}{l}\text { CG } \\
\text { CG }\end{array}$ & $\begin{array}{l}\text { "SW/10\%, CN/90\%" } \\
\text { "SW/10\%, CN/90\%" }\end{array}$ \\
\hline Ephemeropte & r Ephoron & Ephoron album & 6 & 2 & CG & $\mathrm{BU}$ \\
\hline Ephemeropte & r Fallceon & Fallceon quilleri & 17 & 5 & CG & "SW/10\%, CN/90\%" \\
\hline Ephemeropte & r Isonychia & Isonychia campestris & 16 & 2 & $\mathrm{CF}$ & SW/CN \\
\hline Ephemeropte & r Leucrocuta & Leucrocuta & 1 & 1 & SC & $\mathrm{CN}$ \\
\hline Ephemeropte & r Plauditus & Plauditus punctiventris & 1 & 5 & $\mathrm{SC}$ & "SW/10\%, CN/90\%" \\
\hline Ephemeropte & r Traverella & Traverella albertana & 149 & 2 & CF & $\mathrm{CN}$ \\
\hline Ephemeropte & r Tricorythodes & Tricorythodes minutus & 6 & 4 & CG & CN/SP \\
\hline Haplotaxida & Oligochaeta & Tubificidae & 4 & 8 & CG & $\mathrm{BU}$ \\
\hline Odonata & Gomphidae & Ophiogomphus severus & 7 & 2 & PR & $\mathrm{BU}$ \\
\hline Plecoptera & Acroneuria & Acroneuria abnormis & 18 & 0 & PR & $\mathrm{CN}$ \\
\hline Trichoptera & Brachycentrus & Brachycentrus occidentalis & 20 & 1 & CF & $\mathrm{CN}$ \\
\hline Trichoptera & Cheumatopsyche & Cheumatopsyche & 13 & 5 & CF & $\mathrm{CN}$ \\
\hline Trichoptera & \multicolumn{2}{|c|}{ Hydropsyche_Cerato Hydropsyche } & 28 & 5 & CF & $\mathrm{CN}$ \\
\hline Trichoptera & \multicolumn{2}{|c|}{ Hydropsyche_Cerato Hydropsyche morosa gr. } & 2 & 5 & CF & $\mathrm{CN}$ \\
\hline Trichoptera & Nectopsyche & Nectopsyche gracilis & 11 & 2 & $\mathrm{SH}$ & $\mathrm{CM} / \mathrm{SP} / \mathrm{CN}$ \\
\hline Trichoptera & Oecetis & Oecetis & 9 & 8 & PR & $\mathrm{CN} / \mathrm{SP}$ \\
\hline TRICHOPTE & Potamyia & POTAMYIA FLAVA & 16 & 4 & $\mathrm{CF}$ & \\
\hline Trichoptera & Mayatrichia & Mayatrichia ayama & 2 & 5 & $\mathrm{CF}$ & $\mathrm{CN}$ \\
\hline
\end{tabular}




\section{Montana Bioassessment Report}

Waterbody Name: Powder River@WYBorder

Station ID: YLPOW1t1Q

Benthic Sample

17985

Reference

Site Classification:

Latitude:

Rep.

0

Longitude:

STORET Activity ID:

$\mathrm{P} 1-\mathrm{Q} 500-\mathrm{M}$

Collection Date: $\quad 07 / 26 / 2011$

Collection Method: MAC-RW-500

Total Number of Individuals in Sample: $\quad 561$

\section{Sample Taxa List}

\section{Order: OTU name:}

$\begin{array}{ll}\text { Coleoptera } & \text { Microcylloepus } \\ \text { Coleoptera } & \text { Stenelmis } \\ \text { Diptera } & \text { Chironominae } \\ \text { Diptera } & \text { Chironominae } \\ \text { Diptera } & \text { Chironominae } \\ \text { Diptera } & \text { Hemerodromia } \\ \text { Diptera } & \text { Orthocladinae } \\ \text { Diptera } & \text { Simuliidae }\end{array}$

Ephemeropter Acentrella

Ephemeropter Acerpenna

Ephemeropter Baetis

Ephemeropter Baetis

Ephemeropter Camelobaetidius

Ephemeropter Choroterpes

Ephemeropter Cercobrachys

Ephemeropter Ephoron

Ephemeropter Fallceon

Ephemeropter Isonychia

Ephemeropter Leucrocuta

Ephemeropter Raptoheptagenia

Ephemeropter Rhithrogena

Ephemeropter Traverella

Ephemeropter Tricorythodes

Hemiptera Sialis

Lepidoptera Lepidoptera

Odonata Gomphidae

Plecoptera Acroneuria

Trichoptera Brachycentrus

Trichoptera Cheumatopsyche

Trichoptera Helicopsyche

Trichoptera

Trichoptera

Hydropsyche

Hydropsyche_Cerato Hydropsyche morosa gr.

Trichoptera

Trichoptera

Nectopsyche

Mayatrichia

Pisidiidae
FinalID:

Anepeorus rusticus

Melanoides tuberculata

Microcylloepus pusillus

Stenelmis

Acalcarella

Cryptochironomus

Polypedilum

Hemerodromia

Parakiefferiella

Simulium

Acentrella turbida

Acerpenna

Baetis intercalaris

Baetis tricaudatus

Camelobaetidius warreni

Choroterpes albiannulata

Cercobrachys cree

Ephoron album

Fallceon quilleri

Isonychia campestris

Leucrocuta

Raptoheptagenia cruentata

Rhithrogena

Traverella albertana

Tricorythodes minutus

Sialis

Petrophila

Ophiogomphus severus

Acroneuria abnormis

Brachycentrus occidentalis

Helicopsyche borealis

Nectopsyche gracilis

Mayatrichia ayama

Pisidium
Cheumatopsyche

Individuals Tol Val: FFG: Habit:

\section{2}

24

5

2

2

7

2

151

2

3

7

3

3

2

5

1

14
22

7

7
1
1

178

20

1

6

6

15

3

25

2

15

3

5

2

1

CG
SC/CG
CG/CF/PR
CG/CF/PR
CG/CF/PR
PR
CG/SC

$\mathrm{CF}$

CG

SC

CG

CG

CG

CG

CG

CG

CG

$\mathrm{CF}$

SC

unk

CG

$\mathrm{CF}$

CG

PR

$\mathrm{SH}$

PR

PR

CF

CF

SC

CF

$\mathrm{CF}$

$\mathrm{SH}$

CF

$\mathrm{CF}$
"CN/50\%, BU/50\%"

"CN/50\%, BU/50\%"

$\mathrm{BU} / \mathrm{CN} / \mathrm{SP}$

$\mathrm{BU} / \mathrm{CN} / \mathrm{SP}$

$\mathrm{BU} / \mathrm{CN} / \mathrm{SP}$

$S P$

SP/BU

$\mathrm{CN}$

"SW/10\%, CN/90\%" "SW/10\%, CN/90\%" "SW/10\%, CN/90\%" "SW/10\%, CN/90\%" "SW/10\%, CN/90\%" $\mathrm{CN} / \mathrm{SP}$

"SW/10\%, CN/90\%" $\mathrm{BU}$

"SW/10\%, CN/90\%" SW/CN

$\mathrm{CN}$

$\mathrm{CN}$

$\mathrm{CN}$

$\mathrm{CN}$

$\mathrm{CN} / \mathrm{SP}$

"CN,CM,BU"

$\mathrm{CM}$

$\mathrm{BU}$

$\mathrm{CN}$

$\mathrm{CN}$

$\mathrm{CN}$

$\mathrm{CN}$

$\mathrm{CN}$

$\mathrm{CN}$

$\mathrm{CM} / \mathrm{SP} / \mathrm{CN}$

$\mathrm{CN}$

$\mathrm{BU}$ 


\section{Montana Bioassessment Report}

Waterbody Name: Powder River@drycreek Station ID: YLPOW2t1

Reference

STORET Activity ID:

Rep.

Site Classification:

Collection Date: $\quad 07 / 26 / 2011$

Latitude:

Collection Method: MAC-TR-500

Longitude:

Total Number of Individuals in Sample: $\quad 629$

\section{Sample Taxa List}

$\begin{array}{ll}\text { Order: } & \text { OTU name: } \\ \text { Coleoptera } & \text { Dubiraphia } \\ \text { Coleoptera } & \text { Microcylloepus } \\ \text { Coleoptera } & \text { Stenelmis } \\ \text { Diptera } & \text { Chironominae } \\ \text { Diptera } & \text { Chironominae } \\ \text { Diptera } & \text { Dicranota } \\ \text { Diptera } & \text { Hemerodromia } \\ \text { Diptera } & \text { Simuliidae }\end{array}$

Ephemeropter Camelobaetidius Ephemeropter Cercobrachys

Ephemeropter Ephoron

Ephemeropter Fallceon

Ephemeropter Isonychia

Ephemeropter Leucrocuta

Ephemeropter Plauditus

Ephemeropter Traverella

Ephemeropter Tricorythodes

Haplotaxida Oligochaeta

Plecoptera Acroneuria

Trichoptera Brachycentrus

Trichoptera

Trichoptera

Trichoptera

Trichoptera

TRICHOPTE Potamyia

Trichoptera

Mayatrichia

Cheumatopsyche
FinalID:

Dubiraphia

Microcylloepus pusillus

Stenelmis

Cladotanytarsus

Cryptochironomus

Dicranota

Hemerodromia

Simulium

Camelobaetidius warreni

Cercobrachys cree

Ephoron album

Fallceon quilleri

Isonychia campestris

Leucrocuta

Plauditus punctiventris

Traverella albertana

Tricorythodes minutus

Tubificidae

Acroneuria abnormis

Brachycentrus occidentalis

Cheumatopsyche

Hydropsyche_Cerato Hydropsyche

Nectopsyche Nectopsyche gracilis

Oecetis

POTAMYIA FLAVA

Mayatrichia ayama

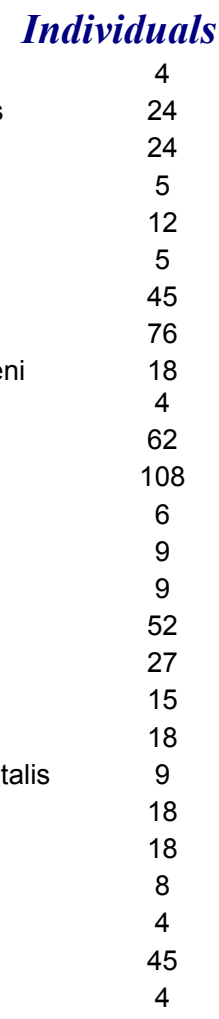

Tol Vat:

$\boldsymbol{F F G}:$
SC/CG
CG
SC/CG
CG/CF/PR
CG/CF/PR

Habit:

"CN/50\%, BU/50\%"

"CN/50\%, BU/50\%"

"CN/50\%, BU/50\%"

$\mathrm{BU} / \mathrm{CN} / \mathrm{SP}$

$\mathrm{BU} / \mathrm{CN} / \mathrm{SP}$

PR

PR

$\mathrm{CF}$

CG

CG

CG

$\mathrm{CG}$

$\mathrm{CF}$

$\mathrm{SC}$

SC

$\mathrm{CF}$

CG

CG

PR

$\mathrm{CF}$

$\mathrm{CF}$

$\mathrm{CF}$

$\mathrm{SH}$

PR

$\mathrm{CF}$

$\mathrm{CF}$
$\mathrm{SP}$

$\mathrm{SP}$

$\mathrm{CN}$

"SW/10\%, CN/90\%"

"SW/10\%, CN/90\%" $\mathrm{BU}$

"SW/10\%, CN/90\%" SW/CN

$\mathrm{CN}$

"SW/10\%, CN/90\%"

$\mathrm{CN}$

$\mathrm{CN} / \mathrm{SP}$

BU

$\mathrm{CN}$

$\mathrm{CN}$

$\mathrm{CN}$

$\mathrm{CN}$

$\mathrm{CM} / \mathrm{SP} / \mathrm{CN}$

$\mathrm{CN} / \mathrm{SP}$

CN 


\section{Montana Bioassessment Report}

Waterbody Name: Powder River@drycreek

Benthic Sample

17987

Station ID: YLPOW2t1Q

Rep.

0

Reference

Site Classification:

Latitude:

Longitude:
STORET Activity ID:

$\mathrm{P} 2-\mathrm{Q} 500-\mathrm{M}$

Collection Date:

$07 / 26 / 2011$

Collection Method: MAC-RW-500

Total Number of Individuals in Sample: 618

\section{Sample Taxa List}

\begin{tabular}{|c|c|c|c|c|c|c|}
\hline Order: & oTU name: & $\begin{array}{l}\text { FinalID: In } \\
\text { Choroterpes albiannulata }\end{array}$ & Individuals & Tol Val: & $F F G:$ & Habit: \\
\hline \multicolumn{2}{|c|}{ Basommatoph Ferrissia } & Ferrissia rivularis & 2 & 6 & SC & $\mathrm{CN}$ \\
\hline \multicolumn{2}{|c|}{ Basommatoph Lymnaeidae } & Fossaria & 2 & 6 & CG & $\mathrm{CN}$ \\
\hline \multicolumn{2}{|c|}{ BasommatophPhysa_Physella } & Physella acuta & 8 & 8 & CG & $\mathrm{CN}$ \\
\hline \multicolumn{2}{|c|}{ Basommatoph Planorbidae } & Menetus & 2 & 6 & CG & $\mathrm{CN}$ \\
\hline Coleoptera & Microcylloepus & Microcylloepus pusillus & 10 & 5 & CG & "CN/50\%, BU/50\%" \\
\hline Coleoptera & Stenelmis & Stenelmis & 4 & 5 & SC/CG & "CN/50\%, BU/50\%" \\
\hline Diptera & Chironominae & Acalcarella & 24 & 7 & CG/CF/PR & $\mathrm{BU} / \mathrm{CN} / \mathrm{SP}$ \\
\hline Diptera & Chironominae & Cryptochironomus & 50 & 7 & CG/CF/PR & $\mathrm{BU} / \mathrm{CN} / \mathrm{SP}$ \\
\hline Diptera & Chironominae & Polypedilum & 12 & 7 & CG/CF/PR & $\mathrm{BU} / \mathrm{CN} / \mathrm{SP}$ \\
\hline Diptera & Chironominae & Robackia & 4 & 7 & CG/CF/PR & $\mathrm{BU} / \mathrm{CN} / \mathrm{SP}$ \\
\hline Diptera & Hemerodromia & Hemerodromia & 6 & 6 & PR & SP \\
\hline Diptera & Orthocladiinae & Parakiefferiella & 2 & & CG/SC & SP/BU \\
\hline Diptera & Simuliidae & Simulium & 268 & 6 & CF & $\mathrm{CN}$ \\
\hline \multicolumn{2}{|c|}{ Ephemeropter Acentrella } & Acentrella turbida & 8 & 4 & CG & "SW/10\%, CN/90\%" \\
\hline \multirow{2}{*}{\multicolumn{2}{|c|}{$\begin{array}{l}\text { Ephemeropter Baetis } \\
\text { Ephemeropter Cercobrachys }\end{array}$}} & Baetis tricaudatus & 4 & $\begin{array}{l}5 \\
4\end{array}$ & CG & "SW/10\%, CN/90\%" \\
\hline & & $\begin{array}{l}\text { Cercobrachys cree } \\
\text { Ephoron album }\end{array}$ & $\begin{array}{c}6 \\
18\end{array}$ & $\begin{array}{l}4 \\
2\end{array}$ & & $\begin{array}{c}\text { "SW/10\%, CN/90\%" } \\
\text { BU }\end{array}$ \\
\hline Ephemeropter Ephoron & Ephemeropter Fallceon & $\begin{array}{l}\text { Ephoron album } \\
\text { Fallceon quilleri }\end{array}$ & $\begin{array}{l}18 \\
16\end{array}$ & $\begin{array}{l}2 \\
5\end{array}$ & $\begin{array}{l}C G \\
C G\end{array}$ & "SW/10\%, CN/90\%" \\
\hline \multicolumn{2}{|c|}{ Ephemeropter Hexagenia } & Hexagenia limbata & 2 & 6 & CG & $\mathrm{BU}$ \\
\hline \multicolumn{2}{|c|}{ Ephemeropter Isonychia } & Isonychia campestris & 6 & 2 & $\mathrm{CF}$ & SW/CN \\
\hline \multicolumn{2}{|c|}{ Ephemeropter Leucrocuta } & Leucrocuta & 5 & 1 & SC & $\mathrm{CN}$ \\
\hline \multicolumn{2}{|c|}{ Ephemeropter Oligoneuriidae } & Homoeoneuria alleni & 4 & 2 & unk & $\mathrm{CN} / \mathrm{BU}$ \\
\hline \multicolumn{2}{|c|}{ Ephemeropter Raptoheptagenia } & Raptoheptagenia cruentata & 2 & & unk & $\mathrm{CN}$ \\
\hline \multicolumn{2}{|c|}{ Ephemeropter Rhithrogena } & Rhithrogena & 2 & 0 & CG & $\mathrm{CN}$ \\
\hline \multicolumn{2}{|c|}{ Ephemeropter Traverella } & Traverella albertana & 70 & 2 & $\mathrm{CF}$ & $\mathrm{CN}$ \\
\hline \multicolumn{2}{|c|}{ Ephemeropter Tricorythodes } & Tricorythodes minutus & 18 & 4 & CG & $\mathrm{CN} / \mathrm{SP}$ \\
\hline Odonata & Gomphidae & Ophiogomphus severus & 4 & 2 & PR & $\mathrm{BU}$ \\
\hline Plecoptera & Acroneuria & Acroneuria abnormis & 10 & 0 & PR & $\mathrm{CN}$ \\
\hline Trichoptera & Brachycentrus & Brachycentrus occidentalis & 2 & 1 & $\mathrm{CF}$ & $\mathrm{CN}$ \\
\hline Trichoptera & Cheumatopsyche & Cheumatopsyche & 14 & 5 & CF & $\mathrm{CN}$ \\
\hline Trichoptera & \multicolumn{2}{|c|}{ Hydropsyche_Cerato Hydropsyche confusa } & 4 & 5 & $\mathrm{CF}$ & $\mathrm{CN}$ \\
\hline Trichoptera & \multicolumn{2}{|c|}{ Hydropsyche_Cerato Hydropsyche morosa gr. } & 4 & 5 & $\mathrm{CF}$ & $\mathrm{CN}$ \\
\hline Trichoptera & Nectopsyche & Nectopsyche gracilis & 19 & 2 & $\mathrm{SH}$ & $\mathrm{CM} / \mathrm{SP} / \mathrm{CN}$ \\
\hline
\end{tabular}




\section{Montana Bioassessment Report}

Waterbody Name: Powder River@MooreheadBridge

Rep.

Reference

Site Classification:

Latitude:

Longitude:
STORET Activity ID:

$\mathrm{PM}-\mathrm{T} 500-\mathrm{M}$

Collection Date:

$07 / 26 / 2011$

Collection Method:

MAC-TR-500

Total Number of Individuals in Sample: $\quad 603$

\section{Sample Taxa List}

\section{Order: $\quad$ OTU name:}

$\begin{array}{ll}\text { Coleoptera } & \text { Microcylloepus } \\ \text { Coleoptera } & \text { Stenelmis } \\ \text { Diptera } & \text { Chironominae } \\ \text { Diptera } & \text { Chironominae } \\ \text { Diptera } & \text { Chironominae } \\ \text { Diptera } & \text { Hemerodromia } \\ \text { Diptera } & \text { Simuliidae }\end{array}$

Ephemeropter Acentrella

Ephemeropter Camelobaetidius

Ephemeropter Ephoron

Ephemeropter Fallceon

Ephemeropter Isonychia

Ephemeropter Leucrocuta

Ephemeropter Pseudocloeon

Ephemeropter Rhithrogena

Ephemeropter Traverella

Ephemeropter Tricorythodes

Odonata

Gomphidae

Plecoptera

Acroneuria

Trichoptera

Trichoptera

Trichoptera

Trichoptera

Trichoptera

Trichoptera

Brachycentrus

Cheumatopsyche

Hydropsyche_CeratoHydropsyche

Hydropsyche_CeratoHydropsyche morosa gr.

Nectopsyche

Oecetis

TRICHOPTE Potamyia

Trombidiforme Acarina
FinalID:

Melanoides tuberculata

Microcylloepus pusillus

Stenelmis

Cryptochironomus

Polypedilum

Robackia

Hemerodromia

Simulium

Acentrella turbida

Camelobaetidius warreni

Ephoron album

Fallceon quilleri

Isonychia campestris

Leucrocuta

Pseudocloeon

Rhithrogena

Traverella albertana

Tricorythodes minutus

Ophiogomphus severus

Acroneuria abnormis

Brachycentrus occidentalis

Cheumatopsyche

Nectopsyche gracilis

Oecetis

POTAMYIA FLAVA

Hygrobates
Individuals Tol Val: FFG:

12

14

2

2

10

308

1

8

7

14

14

2

1

2

3

3
84

6

2

8

12

2
Habit:

"CN/50\%, BU/50\%"

"CN/50\%, BU/50\%"

$\mathrm{BU} / \mathrm{CN} / \mathrm{SP}$

$\mathrm{BU} / \mathrm{CN} / \mathrm{SP}$

$\mathrm{BU} / \mathrm{CN} / \mathrm{SP}$

$\mathrm{SP}$

$\mathrm{CN}$

"SW/10\%, CN/90\%"

"SW/10\%, CN/90\%" $\mathrm{BU}$

"SW/10\%, CN/90\%" SW/CN

$\mathrm{CN}$

"SW/10\%, CN/90\%"

$$
\mathrm{CN}
$$

$\mathrm{CN}$

$\mathrm{CN} / \mathrm{SP}$

BU

$\mathrm{CN}$

$\mathrm{CN}$

$\mathrm{CN}$

$\mathrm{CN}$

CN

CM/SP/CN

$\mathrm{CN} / \mathrm{SP}$

"SW/10\%, CN/90\%" 


\section{Montana Bioassessment Report}

Waterbody Name: Powder River@MooreheadBridge

Benthic Sample

17995

Station ID: YLPOWMt1Q

Rep.

0

Reference

Site Classification:

Latitude:

Longitude:
STORET Activity ID:

PM-Q500-M

Collection Date: $\quad$ 07/26/2011

Collection Method: MAC-RW-500

Total Number of Individuals in Sample: $\quad 607$

\section{Sample Taxa List}

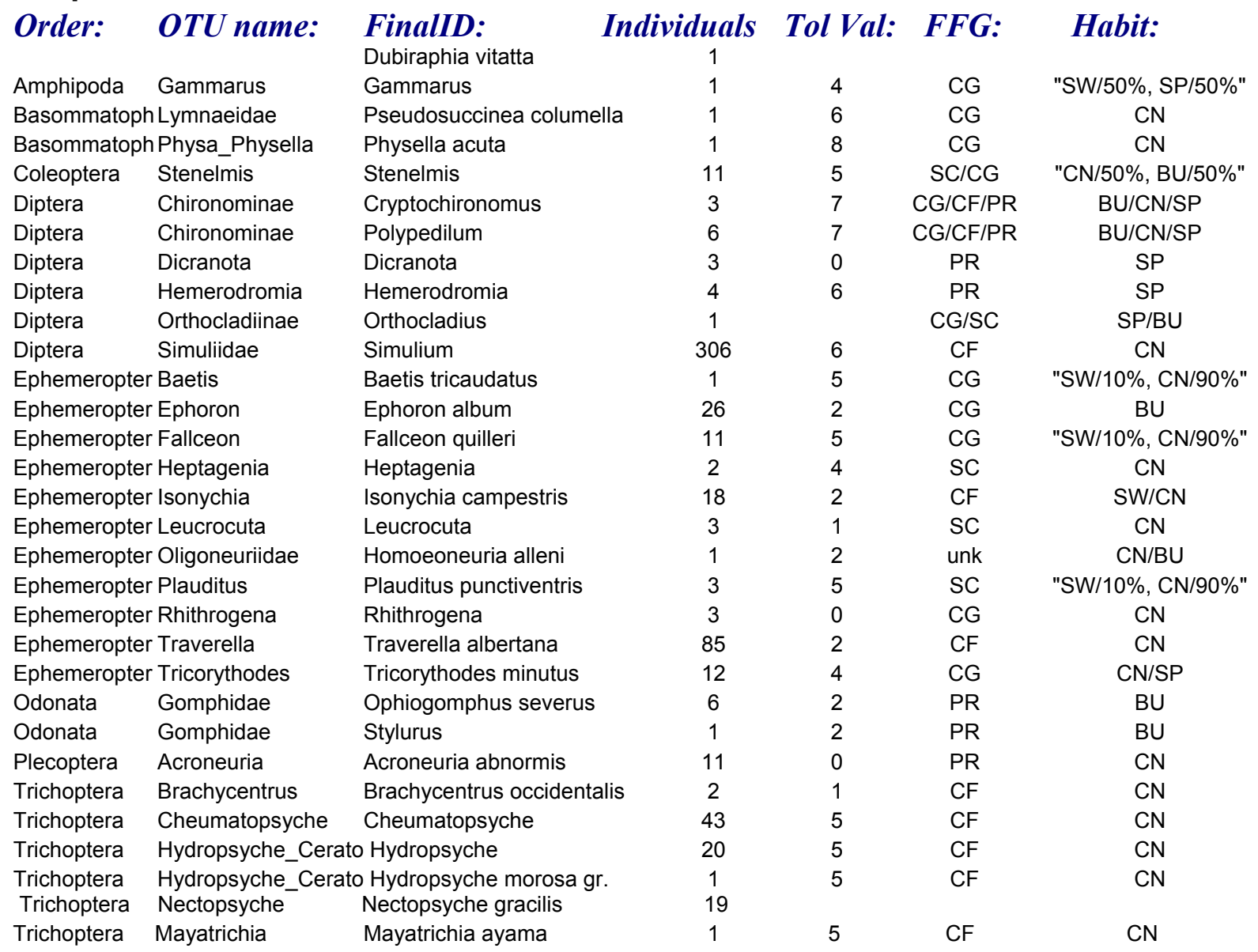




\section{Montana Bioassessment Report}

Waterbody Name: Powder River@Jenkins Station ID: YLPOW3t1
Benthic Sample

17988

Rep.

0

Reference

Site Classification:

Latitude:

STORET Activity ID:

P3-T500-M

Collection Date:

$07 / 27 / 2011$

Collection Method:

MAC-TR-500

Total Number of Individuals in Sample: $\quad 558$

\section{Sample Taxa List}

Order:

OTU name:

Coleoptera

Coleoptera

Diptera

Diptera

Diptera

Diptera

Diptera

Microcylloepus

Stenelmis

Chironominae

Chironominae

Chironominae

Hemerodromia

Simuliidae

Ephemeropter Camelobaetidius

Ephemeropter Ephoron

Ephemeropter Fallceon

Ephemeropter Heptagenia

Ephemeropter Isonychia

Ephemeropter Leucrocuta

Ephemeropter Plauditus

Ephemeropter Raptoheptagenia

Ephemeropter Traverella

Ephemeropter Tricorythodes

Haplotaxida Oligochaeta

Odonata Gomphidae

Plecoptera

Plecoptera

Trichoptera

Trichoptera

Trichoptera

Trichoptera

Trichoptera

TRICHOPTE Potamyia

Trichoptera Mayatrichia

Nectopsyche
FinalID:

Microcylloepus pusillus

Stenelmis

Cryptochironomus

Polypedilum

Robackia

Hemerodromia

Simulium

Camelobaetidius warreni

Ephoron album

Fallceon quilleri

Heptagenia

Isonychia campestris

Leucrocuta

Plauditus punctiventris

Raptoheptagenia cruentata

Traverella albertana

Tricorythodes minutus

Tubificidae

Ophiogomphus severus

Acroneuria abnormis

Isoperla

Brachycentrus occidentalis

Cheumatopsyche

Hydropsyche_Cerato Hydropsyche

Nectopsyche gracilis

Oecetis

POTAMYIA FLAVA

Mayatrichia ayama
Individuals

\section{8}

18

12

6

6

10

108

2

36

24

2

24

4

2

2

110

22

2

14

20

2

12

38

38

14

12

6
Tol Val: FFG:

$\mathrm{CG}$

SC/CG

CG/CF/PR

CG/CF/PR

$\mathrm{CG} / \mathrm{CF} / \mathrm{PR}$

PR

CF

CG

CG

CG

SC

CF

$\mathrm{SC}$

SC

unk

CF

CG

CG

PR

PR

PR

CF

CF

CF

$\mathrm{SH}$

PR

CF

$\mathrm{CF}$
Habit:

"CN/50\%, BU/50\%"

"CN/50\%, BU/50\%"

$\mathrm{BU} / \mathrm{CN} / \mathrm{SP}$

$\mathrm{BU} / \mathrm{CN} / \mathrm{SP}$

$\mathrm{BU} / \mathrm{CN} / \mathrm{SP}$

$\mathrm{SP}$

$\mathrm{CN}$

"SW/10\%, CN/90\%" $\mathrm{BU}$

"SW/10\%, CN/90\%"

$\mathrm{CN}$

SW/CN

$\mathrm{CN}$

"SW/10\%, CN/90\%"

$\mathrm{CN}$

$\mathrm{CN}$

$\mathrm{CN} / \mathrm{SP}$

$\mathrm{BU}$

BU

$\mathrm{CN}$

$\mathrm{CN}$

$\mathrm{CN}$

$\mathrm{CN}$

$\mathrm{CN}$

$\mathrm{CM} / \mathrm{SP} / \mathrm{CN}$

$\mathrm{CN} / \mathrm{SP}$

$\mathrm{CN}$ 


\section{Montana Bioassessment Report}

Waterbody Name: Powder River@Jenkins

Benthic Sample

17989

Station ID: YLPOW3t1Q

Rep.

0

Reference

Site Classification:

Latitude:

Longitude:
STORET Activity ID:

P3-Q500-M

Collection Date:

$07 / 27 / 2011$

Collection Method: MAC-RW-500

Total Number of Individuals in Sample: $\quad 385$

\section{Sample Taxa List}

Order: OTU name:

Basommatoph Lymnaeidae

Coleoptera Stenelmis

Diptera Chironominae

Diptera Chironominae

Diptera Hemerodromia

Diptera Orthocladiinae

Diptera Orthocladiinae

Diptera Simuliidae

Ephemeropter Baetis

Ephemeropter Camelobaetidius

Ephemeropter Ephoron

Ephemeropter Fallceon

Ephemeropter Isonychia

Ephemeropter Leucrocuta

Ephemeropter Oligoneuriidae

Ephemeropter Plauditus

Ephemeropter Rhithrogena

Ephemeropter Traverella

Ephemeropter Tricorythodes

Odonata

Gomphidae

Plecoptera

Trichoptera

Trichoptera

Trichoptera

Trichoptera

Brachycentrus

Cheumatopsyche

Nectopsyche

FinalID:

Individuals

Pseudosuccinea columella

Stenelmis

Acalcarella

Cryptochironomus

Hemerodromia

Orthocladius

Parakiefferiella

Simulium

Baetis intercalaris

Camelobaetidius warreni

Ephoron album

Fallceon quilleri

Isonychia campestris

Leucrocuta

Homoeoneuria alleni

Plauditus punctiventris

Rhithrogena

Traverella albertana

Tricorythodes minutus

Ophiogomphus severus

Acroneuria abnormis

Brachycentrus occidentalis

Hydropsyche_Cerato Hydropsyche

Nectopsyche

Tol Val:

6

5

7

7

7

6

165

3

3

4
23

16

2

7

3

3

31

31

1

8

8

21

1

21

$\boldsymbol{F F G}:$
CG
SC/CG
CG/CF/PR
CG/CF/PR
PR
CG/SC
CG/SC
CF
CG
CG
CG
CG
CF
SC
unk
SC
CG
CF
CG
PR
PR
CF
CF
CF
SH

Habit:

$\mathrm{CN}$

"CN/50\%, BU/50\%"

$\mathrm{BU} / \mathrm{CN} / \mathrm{SP}$

$\mathrm{BU} / \mathrm{CN} / \mathrm{SP}$

$\mathrm{SP}$

SP/BU

SP/BU

$\mathrm{CN}$

"SW/10\%, CN/90\%"

"SW/10\%, CN/90\%"

$\mathrm{BU}$

"SW/10\%, CN/90\%"

SW/CN

$\mathrm{CN}$

$\mathrm{CN} / \mathrm{BU}$

"SW/10\%, CN/90\%"

$\mathrm{CN}$

$\mathrm{CN}$

$\mathrm{CN} / \mathrm{SP}$

$\mathrm{BU}$

$\mathrm{CN}$

$\mathrm{CN}$

$\mathrm{CN}$

$\mathrm{CN}$

$\mathrm{CM} / \mathrm{SP} / \mathrm{CN}$ 


\section{Montana Bioassessment Report}

Waterbody Name: Powder River@RoughCreek

Rep.

Reference

Site Classification:

Latitude:

Longitude:

\section{Sample Taxa List}

$\begin{array}{ll}\text { Order: } & \text { OTU name: } \\ \text { Coleoptera } & \text { Stenelmis } \\ \text { Diptera } & \text { Chironominae } \\ \text { Diptera } & \text { Chironominae } \\ \text { Diptera } & \text { Chironominae } \\ \text { Diptera } & \text { Hemerodromia } \\ \text { Diptera } & \text { Simuliidae } \\ \text { Ephemeropter Acerpenna } & \\ \text { Ephemeropter Asioplax } & \\ \text { Ephemeropter Anepeorus } \\ \text { Ephemeropter Camelobaetidius } \\ \text { Ephemeropter Cercobrachys } \\ \text { Ephemeropter Ephoron } \\ \text { Ephemeropter Fallceon } \\ \text { Ephemeropter Isonychia } \\ \text { Ephemeropter Neochoroterpes } \\ \text { Ephemeropter Pseudocloeon } \\ \text { Ephemeropter Traverella } \\ \text { Ephemeropter Tricorythodes } \\ \text { Haplotaxida } & \text { Oligochaeta } \\ \text { Odonata } & \text { Gomphidae } \\ \text { Plecoptera } & \text { Acroneuria } \\ \text { Trichoptera } & \text { Brachycentrus } \\ \text { Trichoptera } & \text { Nectopsyche } \\ \text { Trichoptera } & \text { Oecetis } \\ \text { TRICHOPTE } & \text { Potamyia } \\ & \end{array}$

FinalID:

Stenelmis

Cryptochironomus

Polypedilum

Robackia

Hemerodromia

Simulium

Acerpenna pygmaea

Asioplax edmundsi

Anepeorus rusticus

Camelobaetidius warreni

Cercobrachys cree

Ephoron album

Fallceon quilleri

Isonychia campestris

Neochoroterpes oklahoma

Pseudocloeon

Traverella albertana

Tricorythodes minutus

Tubificidae

Ophiogomphus severus

Acroneuria abnormis

Brachycentrus occidentalis

Nectopsyche gracilis

Oecetis

POTAMYIA FLAVA
STORET Activity ID:

P5-T500-M

Collection Date:

07/27/2011

Collection Method:

MAC-TR-500

Total Number of Individuals in Sample: 603

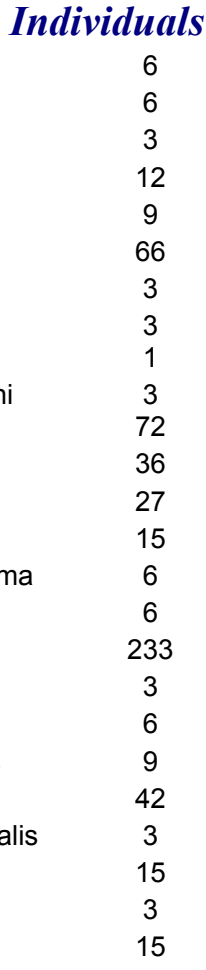

Tol Val:

5

7

7

7

6

6

$\begin{array}{cc}\text { FFG: } & \text { Habit: } \\ \text { SC/CG } & \text { "CN/50\%, BU/50\%" } \\ \text { CG/CF/PR } & \text { BU/CN/SP } \\ \text { CG/CF/PR } & \text { BU/CN/SP } \\ \text { CG/CF/PR } & \text { BU/CN/SP } \\ \text { PR } & \text { SP } \\ \text { CF } & \text { CN }\end{array}$

"SW/10\%, CN/90\%"

$\mathrm{CN} / \mathrm{SP}$

"SW/10\%, CN/90\%"

"SW/10\%, CN/90\%"

$\mathrm{BU}$

"SW/10\%, CN/90\%"

SW/CN

$\mathrm{CN} / \mathrm{SP}$

"SW/10\%, CN/90\%"

$\mathrm{CN}$

$\mathrm{CN} / \mathrm{SP}$

$\mathrm{BU}$

$\mathrm{BU}$

$\mathrm{CN}$

CN

$\mathrm{CM} / \mathrm{SP} / \mathrm{CN}$

CN/SP 


\section{Montana Bioassessment Report}

Waterbody Name: Powder River@RoughCreek

Benthic Sample

17991

Station ID: YLPOW5t1Q

Rep.

0

Reference

Site Classification:

STORET Activity ID: $\quad$ P5-Q500-M

Latitude:

Collection Date:

$07 / 27 / 2011$

Collection Method: MAC-RW-500

Longitude:

Total Number of Individuals in Sample:

394

\section{Sample Taxa List}

Order: OTU name:

Basommatoph Physa_Physella

Coleoptera Stenelmis

Diptera Chironominae

Diptera Chironominae

Diptera Hemerodromia

Diptera Orthocladiinae

Diptera Simuliidae

Ephemeropter Ephoron

Ephemeropter Cercobrachys

Ephemeropter Fallceon

Ephemeropter Isonychia

Ephemeropter Leucrocuta

Ephemeropter Oligoneuriidae

Ephemeropter Traverella

Ephemeropter Tricorythodes

Odonata Gomphidae

Plecoptera Acroneuria

Trichoptera

Trichoptera

Trichoptera

Trichoptera

Veneroida

Cheumatopsyche

Hydropsyche_Cerato Hydropsyche

Nectopsyche

Mayatrichia

Pisidiidae

Hemerodromia
FinalID:

Physella acuta

Stenelmis

Cryptochironomus

Polypedilum

Parakiefferiella

Simulium

Ephoron album

Cercobrachys cree

Fallceon quilleri

Isonychia campestris

Leucrocuta

Homoeoneuria alleni

Traverella albertana

Tricorythodes minutus

Ophiogomphus severus

Acroneuria abnormis

Cheumatopsyche

Nectopsyche gracilis

Mayatrichia ayama

Sphaerium
Individuals

1
3
2
4
4
3
6
39
29
3
22
2
23
166
8
4
41
22
2
8
1
1

Tol Val: FFG: Habit:

CG $\mathrm{CN}$

SC/CG "CN/50\%, BU/50\%"

CG/CF/PR $\quad B U / C N / S P$

$\mathrm{CG} / \mathrm{CF} / \mathrm{PR} \quad \mathrm{BU} / \mathrm{CN} / \mathrm{SP}$

PR SP

$\mathrm{CG} / \mathrm{SC}$

$\mathrm{CF}$

CG

CG

CG

$\mathrm{CF}$

SC

unk

CF

CG

PR

PR

$\mathrm{CF}$

$\mathrm{CF}$

$\mathrm{SH}$

$\mathrm{CF}$

$\mathrm{CF}$
$S P / B U$

$\mathrm{CN}$

$\mathrm{BU}$

"SW/10\%, CN/90\%"

"SW/10\%, CN/90\%"

SW/CN

$\mathrm{CN}$

$\mathrm{CN} / \mathrm{BU}$

$\mathrm{CN}$

CN/SP

$\mathrm{BU}$

$\mathrm{CN}$

$\mathrm{CN}$

$\mathrm{CN}$

$\mathrm{CM} / \mathrm{SP} / \mathrm{CN}$

$\mathrm{CN}$

$\mathrm{BU}$ 


\section{Montana Bioassessment Report}

Waterbody Name: Powder River@buttermilk Station ID: YLPOW6t1

Benthic Sample

17992

Rep.

0

Reference

Site Classification:

STORET Activity ID:

P6-T500-M

Collection Date:

$07 / 27 / 2011$

Latitude:

Collection Method:

MAC-TR-500

Longitude:

Total Number of Individuals in Sample:

631

\section{Sample Taxa List}

Order: OTU name

$\begin{array}{ll}\text { Diptera } & \text { Chironominae } \\ \text { Diptera } & \text { Chironominae } \\ \text { Diptera } & \text { Chironominae } \\ \text { Diptera } & \text { Diamesinae } \\ \text { Diptera } & \text { Hemerodromia } \\ \text { Diptera } & \text { Simuliidae } \\ \text { Ephemeropter } & \text { Baetis } \\ \text { Ephemeropter Cercobracys } \\ \text { Ephemeropter } & \text { Ephoron } \\ \text { Ephemeropter Fallceon } \\ \text { Ephemeropter Heptagenia } \\ \text { Ephemeropter Isonychia } \\ \text { Ephemeropter Leucrocuta } \\ \text { Ephemeropter Plauditus } \\ \text { Ephemeropter Pseudocloeon } \\ \text { Ephemeropter } & \text { Traverella } \\ \text { Ephemeropter } & \text { Tricorythodes } \\ \text { Plecoptera } & \text { Acroneuria } \\ \text { Plecoptera } & \text { Isoperla } \\ \text { Trichoptera } & \text { Cheumatopsyche } \\ \text { Trichoptera } & \text { Nectopsyche } \\ \text { Trichoptera } & \text { Oecetis } \\ \text { Trichopte } & \text { Potamyia } \\ \text { Veneroida } & \text { Pisidiidae }\end{array}$

FinalID:

Melanoides tuberculata

Cryptochironomus

Polypedilum

Robackia

Potthastia

Hemerodromia

Simulium

Baetis intercalaris

Cercobrachys cree

Ephoron album

Fallceon quilleri

Heptagenia

Isonychia campestris

Leucrocuta

Plauditus punctiventris

Pseudocloeon

Traverella albertana

Tricorythodes minutus

Acroneuria abnormis

Isoperla

Cheumatopsyche

Nectopsyche gracilis

Oecetis

Potamyia flava

Sphaerium
Individuals Tol Val: FFG:

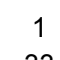

33

21

15

1

27

75

6

12

12

21

3

3

3

3

36

298

3

24

6

3

15

1

6

3

CG/CF/PR
CG/CF/PR
CG/CF/PR
CG
PR
CF
CG
CG
CG
CG
SC
CF
SC
SC
CG
CF
CG
PR
PR
CF
SH
PR
CF
CF

Habit:

$\mathrm{BU} / \mathrm{CN} / \mathrm{SP}$

$\mathrm{BU} / \mathrm{CN} / \mathrm{SP}$

BU/CN/SP

$\mathrm{sp}$

$\mathrm{SP}$

$\mathrm{CN}$

"SW/10\%, CN/90\%"

"SW/10\%, CN/90\%"

$\mathrm{BU}$

"SW/10\%, CN/90\%"

$\mathrm{CN}$

SW/CN

$\mathrm{CN}$

"SW/10\%, CN/90\%"

"SW/10\%, CN/90\%"

$\mathrm{CN}$

CN/SP

$\mathrm{CN}$

$\mathrm{CN}$

$\mathrm{CN}$

$\mathrm{CM} / \mathrm{SP} / \mathrm{CN}$

$\mathrm{CN} / \mathrm{SP}$

BU 


\section{Montana Bioassessment Report}

Waterbody Name: Powder River@buttermilk

Benthic Sample

17993

Station ID: YLPOW6t1Q

Rep.

0

Reference

STORET Activity ID:

P6-Q500-M

Site Classification:

Collection Date:

$07 / 27 / 2011$

Latitude:

Collection Method: MAC-RW-500

Longitude:

Total Number of Individuals in Sample: $\quad 603$

\section{Sample Taxa List}

\begin{tabular}{|c|c|c|c|c|c|c|}
\hline Order: & OTU name: & FinalID: & idividuals & Tol Val: & $F F G:$ & Habit: \\
\hline Coleoptera & Microcylloepus & Microcylloepus pusillus & 1 & 5 & CG & "CN/50\%, BU/50\%" \\
\hline Coleoptera & Stenelmis & Stenelmis & 4 & 5 & SC/CG & "CN/50\%, BU/50\%" \\
\hline Diptera & Chironominae & Cladotanytarsus & 1 & 7 & CG/CF/PR & $\mathrm{BU} / \mathrm{CN} / \mathrm{SP}$ \\
\hline Diptera & Chironominae & Cryptochironomus & 14 & 7 & CG/CF/PR & $\mathrm{BU} / \mathrm{CN} / \mathrm{SP}$ \\
\hline Diptera & Chironominae & Polypedilum & 12 & 7 & CG/CF/PR & $\mathrm{BU} / \mathrm{CN} / \mathrm{SP}$ \\
\hline Diptera & Chironominae & Robackia & 11 & 7 & CG/CF/PR & $\mathrm{BU} / \mathrm{CN} / \mathrm{SP}$ \\
\hline Diptera & Hemerodromia & Hemerodromia & 7 & 6 & PR & SP \\
\hline Diptera & Orthocladiinae & Parakiefferiella & 11 & & $\mathrm{CG} / \mathrm{SC}$ & SP/BU \\
\hline Diptera & Simuliidae & Simulium & 65 & 6 & $\mathrm{CF}$ & $\mathrm{CN}$ \\
\hline Ephemeropte & r Baetis & Baetis tricaudatus & 1 & 5 & CG & "SW/10\%, CN/90\%" \\
\hline Ephemeropte & r Camelobaetidius & Camelobaetidius warreni & 3 & 4 & CG & "SW/10\%, CN/90\%" \\
\hline Ephemeropte & r Cercobracys & Cercobrachys cree & 46 & 4 & CG & "SW/10\%, CN/90\%" \\
\hline Ephemeropte & Ephoron & Ephoron album & 43 & 2 & CG & $\mathrm{BU}$ \\
\hline Ephemeropte & r Fallceon & Fallceon quilleri & 27 & 5 & CG & "SW/10\%, CN/90\%" \\
\hline Ephemeropte & r Isonychia & Isonychia campestris & 21 & 2 & $\mathrm{CF}$ & SW/CN \\
\hline Ephemeropte & r Leucrocuta & Leucrocuta & 3 & 1 & SC & $\mathrm{CN}$ \\
\hline Ephemeropte & Oligoneuriidae & Homoeoneuria alleni & 19 & 2 & unk & $\mathrm{CN} / \mathrm{BU}$ \\
\hline Ephemeropte & r Plauditus & Plauditus punctiventris & 1 & 5 & SC & "SW/10\%, CN/90\%" \\
\hline Ephemeropte & r Raptoheptagenia & Raptoheptagenia cruentata & 3 & & unk & $\mathrm{CN}$ \\
\hline Ephemeropte & Rhithrogena & Rhithrogena & 1 & 0 & CG & $\mathrm{CN}$ \\
\hline Ephemeropte & Traverella & Traverella albertana & 145 & 2 & $\mathrm{CF}$ & $\mathrm{CN}$ \\
\hline Ephemeropte & Tricorythodes & Tricorythodes minutus & 41 & 4 & CG & $\mathrm{CN} / \mathrm{SP}$ \\
\hline Odonata & Gomphidae & Ophiogomphus severus & 3 & 2 & PR & $\mathrm{BU}$ \\
\hline Odonata & Gomphidae & Stylurus & 1 & 2 & PR & $\mathrm{BU}$ \\
\hline Plecoptera & Acroneuria & Acroneuria abnormis & 23 & 0 & PR & $\mathrm{CN}$ \\
\hline Trichoptera & Cheumatopsyche & Cheumatopsyche & 41 & 5 & $\mathrm{CF}$ & $\mathrm{CN}$ \\
\hline Trichoptera & \multicolumn{2}{|c|}{ Hydropsyche_Cerato Hydropsyche } & 10 & 5 & $\mathrm{CF}$ & $\mathrm{CN}$ \\
\hline Trichoptera & Nectopsyche & Nectopsyche gracilis & 45 & 2 & $\mathrm{SH}$ & $\mathrm{CM} / \mathrm{SP} / \mathrm{CN}$ \\
\hline
\end{tabular}

